\title{
Comparative genomic and transcriptome analyses of pathotypes of Xanthomonas citri subsp. citri provide insights into mechanisms of bacterial virulence and host range
}

Neha Jalan ${ }^{1}$, Dibyendu Kumar ${ }^{2}$, Maxuel O Andrade ${ }^{1}$, Fahong Yu ${ }^{3}$, Jeffrey B Jones ${ }^{4}$, James H Graham, Frank F White ${ }^{6}$, João C Setubal ${ }^{7,8}$ and Nian Wang ${ }^{1 *}$

\begin{abstract}
Background: Citrus bacterial canker is a disease that has severe economic impact on citrus industries worldwide and is caused by a few species and pathotypes of Xanthomonas. X. citri subsp. citri strain 306 (XccA306) is a type A (Asiatic) strain with a wide host range, whereas its variant $X$. citri subsp. citri strain $A^{w} 12879$ (Xcaw12879, Wellington strain) is restricted to Mexican lime.

Results: To characterize the mechanism for the differences in host range of XccA and Xcaw, the genome of Xcaw12879 that was completed recently was compared with XccA306 genome. Effectors XopAF and avrGf1 are present in Xcaw12879, but were absent in XccA306. AvrGf1 was shown previously for Xcaw to cause hypersensitive response in Duncan grapefruit. Mutation analysis of XopAF indicates that the gene contributes to Xcaw growth in Mexican lime but does not contribute to the limited host range of Xcaw. RNA-Seq analysis was conducted to compare the expression profiles of Xcaw12879 and XccA306 in Nutrient Broth (NB) medium and XVM2 medium, which induces hrp gene expression. Two hundred ninety two and 281 genes showed differential expression in XVM2 compared to in NB for XccA306 and Xcaw12879, respectively. Twenty-five type 3 secretion system genes were up-regulated in XVM2 for both XccA and Xcaw. Among the 4,370 common genes of Xcaw12879 compared to XccA306, 603 genes in NB and 450 genes in XVM2 conditions were differentially regulated. Xcaw12879 showed higher protease activity than XccA306 whereas Xcaw12879 showed lower pectate lyase activity in comparison to XccA306.

Conclusions: Comparative genomic analysis of XccA306 and Xcaw12879 identified strain specific genes. Our study indicated that AvrGf1 contributes to the host range limitation of Xcaw12879 whereas XopAF contributes to virulence. Transcriptome analyses of XccA306 and Xcaw12879 presented insights into the expression of the two closely related strains of $X$. citri subsp. citri. Virulence genes including genes encoding T3SS components and effectors are induced in XVM2 medium. Numerous genes with differential expression in Xcaw12879 and XccA306 were identified. This study provided the foundation to further characterize the mechanisms for virulence and host range of pathotypes of $X$. citri subsp. citri.
\end{abstract}

Keywords: Xanthomonas citri, Wellington strain, Citrus canker, HR, Virulence, Transcriptome, RNA-Seq

\footnotetext{
* Correspondence: nianwang@ufl.edu

${ }^{1}$ Citrus Research and Education Center, Department of Microbiology and Cell Science, University of Florida, 700 Experiment Station Road, Lake Alfred, FL 33850, USA

Full list of author information is available at the end of the article
} 


\section{Background}

Members of the genus Xanthomonas are capable of infecting at least 124 monocot species and 268 dicot species and provide excellent case studies for understanding plant-microbe interactions [1]. Among the diseases caused by Xanthomonas, citrus canker caused by $X$. citri subsp. citri (Xcc) (syn. $X$. axonopodis pv. citri, $X$. campestris pv. citri, $X$. citri pv. citri) is an important disease that has severe economic impact on citrus industries worldwide. Asiatic (A) type strains are the most widespread and, hence, the most destructive form of citrus canker. The strains induce hyperplasic and hypertrophic (raised) lesions surrounded by oily or water-soaked margins and a yellow halo on leaves, stems, and fruits. Besides Xcc, a second species, $X$. fuscans subsp. aurantifolii (Xau), is also known to cause citrus canker with limited geographic distribution and limited host range. Type B strains of Xau are restricted to South America (Argentina, Uruguay and Paraguay) and cause canker on lemon (C. limon) and Mexican lime (C. aurantifolia). Type B strains can also be found on sweet orange (C. sinensis) and grapefruit (Citrus x paradisi) [2]. Type $\mathrm{C}$ strains of Xau are restricted to Brazil and cause canker only on Mexican lime [3].

Two variants of type A strains have also been identified. The variant designated $A^{*}$ was found in Southeast Asia in the 1990s infecting Mexican lime [4,5]. A second variant, designated as the "Wellington strain", was isolated from Palm Beach County in southern Florida $[4,6]$. DNA hybridization analysis showed that Xcaw is more closely related to XccA and XccA* strains than to XauB and XauC strains [4]. Both Xcaw and XccA have similar symptoms and leaf populations on Mexican lime [7]. $X$. citri subsp. citri pathotype $\mathrm{A}^{\mathrm{w}}$ (Xcaw) are pathogenic on Mexican lime and alemow (C. macrophyla) but not on grapefruit and sweet orange. The Xcaw strains cause a hypersensitive reaction (HR) in grapefruit [7]. The gene avrGf1 was identified in Xcaw strain 12879, and mutation of avrGf1 of Xcaw12879 rendered the mutant virulent on grapefruit, although the symptoms were much reduced as compared to symptoms due to strains of XccA306 [7]. A comprehensive understanding of the molecular mechanisms responsible for the differences in virulence and host range of Xcaw and XccA is lacking.

Comparative genomic analyses of xanthomonads have greatly facilitated our understanding of the virulence factors and host range determinants of different pathogens [8-10]. Comparative genomic analysis of $X$. campestris pv. campestris and XccA306 has been conducted previously to understand the mechanisms of different host range and pathogenic processes of the two Xanthomonas species, which have distinct host ranges [8]. Compared to Xcc, which infects citrus and causes citrus canker, $X$. campestris pv. campestris affects crucifers such as
Brassica and causes black rot. Numerous species-specific genes have been identified which might explain the differing host specificities and pathogenic processes of the two pathogens. Comparative genomic analysis of XccA306 and $X$. axonopodis pv. citrumelo was also conducted recently [9]. X. axonopodis pv. citrumelo F1 is a nursery infecting strain and shows low virulence on citrus compared to that of XccA. Differences in gene contents, such as type III effectors (e.g., PthA), the type IV secretion system, and lipopolysaccharide synthesis were identified and may contribute to the differences in bacterial virulence and host range [9]. Furthermore, sequencing of XauB and XauC strains identified different virulence factors affecting host range of closely related species [10].

Here we conducted comparative genomic analysis of Xcaw12879 and the closely related strain XccA306 using a complete genome sequence of Xcaw12879 to understand the difference in virulence and host range. Recently, we have completed the genome sequencing of Xcaw12879 [11]. We further examined the transcriptomes of both XccA306 and Xcaw12879 by RNA-Seq in nutrient rich condition Nutrient Broth (NB) and in XVM2, which is known to induce hrp gene expression [12]. The comparative genomic and transcriptome analyses will provide the foundation to further characterize the mechanisms for virulence and host range of pathotypes of $X$. citri subsp. citri.

\section{Results}

\section{Multi locus sequencing typing analysis}

Multi locus sequence typing (MLST) based phylogenetic analysis was performed for Xcaw12879 and other Xanthomonas spp. using nine housekeeping genes ( $u v r D$, $\sec A, \operatorname{car} A, \operatorname{rec} A, \operatorname{groEL}, \operatorname{dnaK}, \operatorname{atpD}, \operatorname{gyr} B$, and $\inf B$ ) that are highly conserved in bacteria. The nine protein sequences were aligned and concatenated and then used to construct a maximum-likelihood phylogenetic tree (Figure 1). The results showed that Xcaw12879 is closely related to XccA306. Interestingly, these two citrus canker pathogens form a clade with $X$. citri pv. mangiferaeindicae LMG 941 and $X$. axonopodis pv. punicae LMG 859, which cause bacterial black spot in mango and bacterial leaf blight in pomegranates respectively. Both strains were isolated from India $[13,14]$, a putative origin of XccA. Hence, it is possible that these pathogens have evolved from the same ancestor and evolved to adapt to different hosts. The XccA306 and Xcaw12879 strains share close relationship with the other two citrus canker causing bacteria XauB and XauC (Figure 1). The close relationship between XccA, Xcaw, $\mathrm{XauB}$ and $\mathrm{XauC}$ agrees with the genome-based phylogeny of the genus Xanthomonas [15]. 


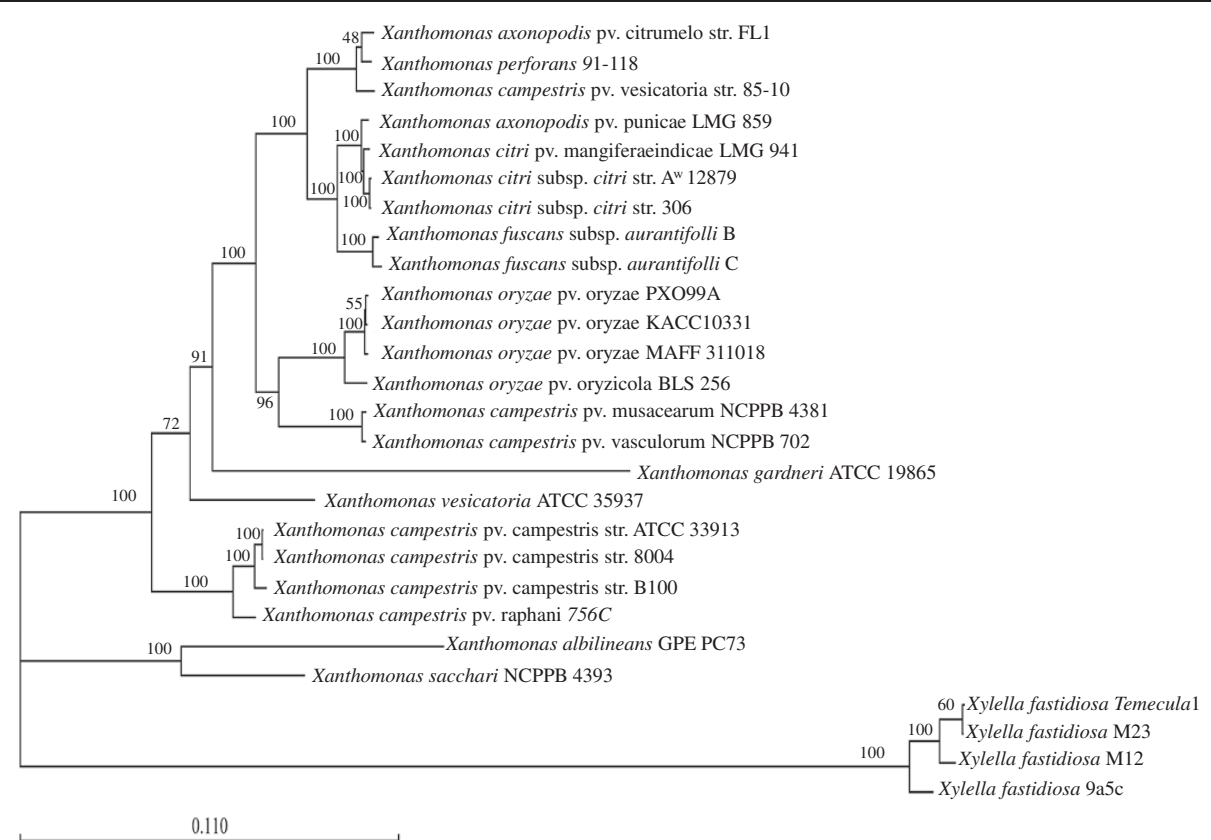

Figure 1 Maximum likelihood phylogenetic tree of the genome of Xanthomonas citri subsp. citri $\mathrm{A}^{\mathrm{w}} 12879$ showing the relationship to other Xanthomonads and related species. The tree was constructed using concatenated protein sequences of nine housekeeping genes (UvrD, SecA, CarA, RecA, GroEL, DnaK, AtpD, GyrB and InfB) aligned using Clustal W. Phylogenic tree from concatenated sequences was constructed in CLC Genomics workbench v6.0 using the Maximum likelihood method. The percentage of replicate trees in which the associated taxa clustered together in the bootstrap test (1000 replicates) are shown next to the branches. Horizontal scale bar (0.11) at the bottom represents number of amino-acid substitutions per site.

\section{Chromosome organization and genome plasticity}

Whole-genome alignment of Xcaw12879 to closely related XccA306 using MAUVE in progressive mode revealed numerous inversions and translocations (Figure 2). Most of the separated blocks in the alignment are associated with integrases and/or IS elements on at least one of their borders. The IS elements have been known to aid horizontal gene transfer and other genome rearrangements [16].

Xcaw12879 genome contains two plasmids pXcaw19 and pXcaw58 that are significantly different from the plasmids found in XccA306. Plasmid pXcaw19 sequence has no similarity with the plasmids of XccA306, whereas pXcaw58 is only about $35 \%$ similar to pXAC64. Plasmid pXcaw58 contains the pthAw2 gene, a homolog of pthA4, which is capable of conferring the ability to cause canker-like symptoms [17]. However, the plasmid pXcaw58 does not contain the Vir like type IV secretion system genes found on pXAC64. The type IV secretion system has been shown to contribute to virulence in $X$. campestris pv. campestris strain 8004 [18] and absence of these genes from the plasmid could affect virulence of Xcaw12879 strain.

Three clustered regularly interspaced short palindromic repeats (CRISPRs) with short (21-47 bp) direct repeats interspaced with unrelated similarly sized non- repetitive sequences (spacers) are found in Xcaw12879 genome (Additional file 1). The CRISPR1 and CRISPR2 repeats are also present in XccA306. CRISPR2 and CRISPR3 from Xcaw12879 are identical except for a G at the beginning of CRISPR2, indicating that it might be a recent duplication. CRISPR is a bacterial immunity system that helps exclude foreign genetic elements. However the variability in Xcaw12879 and XccA306 suggests that the strains might have had dissimilar exposure to foreign genetic material as suggested in $X$. oryzae [19].

The TBLASTN analysis of all the proteins from Xcaw12879 and XccA306 revealed various gene clusters specific to each strain. Of the 4,760 proteins from Xcaw12879 and 4,603 (176 not annotated previously [8]) proteins from XccA306, 4,428 proteins are found to be orthologous using the cut-off e-value $\leq 10^{-10}$ and alignments $>60 \%$ sequence identity, $>60 \%$ query gene length. Among the 4,428 common proteins, 4,252 were annotated in XccA306 [8] whereas 176 are not annotated. Xcaw12879 has 332 proteins that are either nonorthologous to proteins from XccA306 or unique, whereas XccA306 has 175 such proteins.

The hrp and hrc genes encoding the type 3 secretion system (T3SS) in Xcaw12879 are homologous to the hrp and $h r c$ genes found in XccA306. All the genes are 


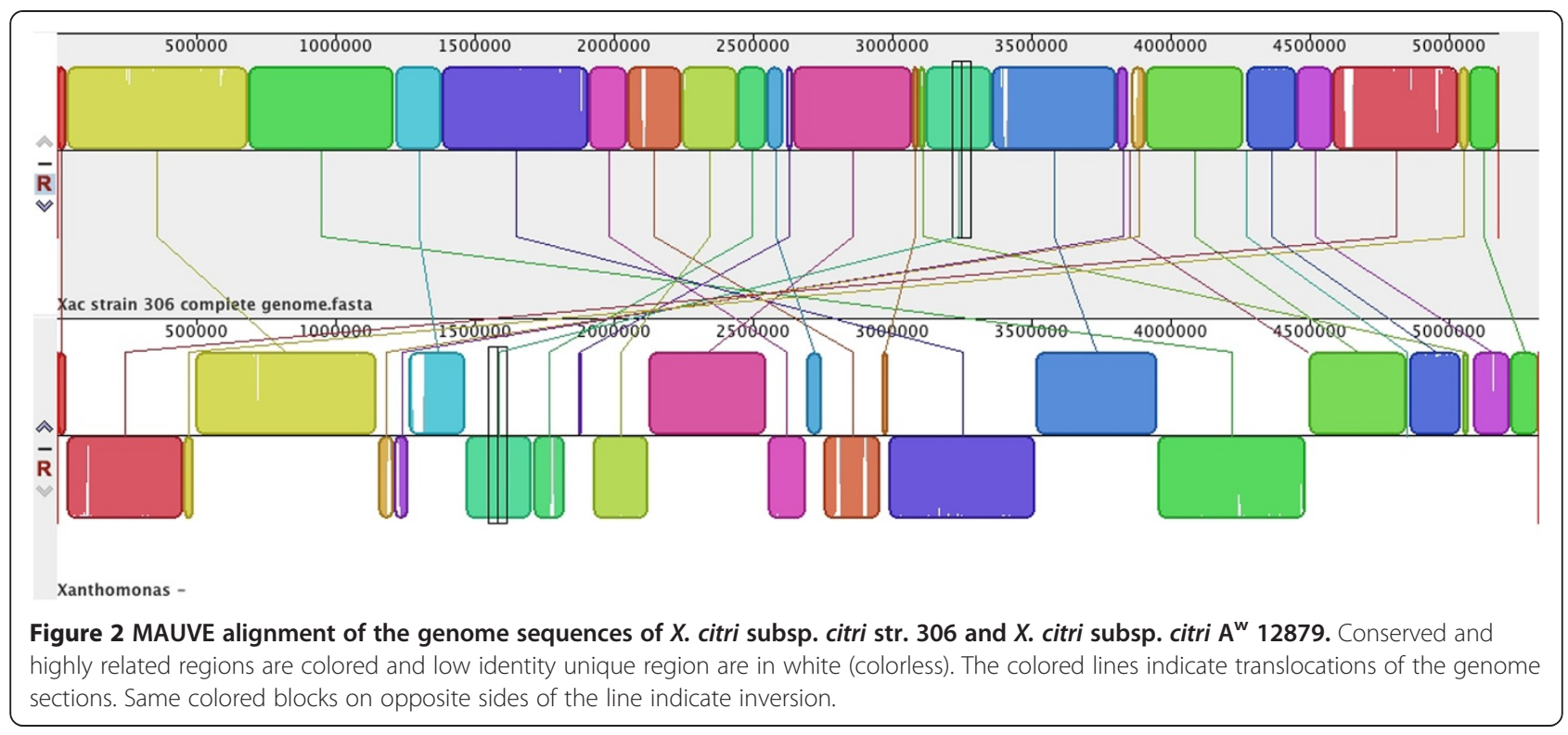

found in similar order with the exception in gene annotation between $h r p F$ and $h p a B$. The genome of XccA306 contains the annotated gene XAC0395 between the two, which is a hypothetical protein. The annotation in Xcaw12879 in the same region is on the opposite strand and contains hpaI (XCAW_00803) and xopF1 (XC AW_00804/XCAW_00805) which may be nonfunctional due to a frameshift. The nucleotide sequences in both strains are the same and the differences in annotation were confirmed by BLAST similarity of the annotated genes in Xcaw12879 to other xanthomonads.

The T3SS translocates effector proteins into the plant cells. The effectors can either aid in nutrient acquisition and virulence or act as avirulence factors that trigger host immune response [20]. The type III effector genes in Xcaw12879 were predicted by BLAST analysis against the known T3SS effector database [http://www. xanthomonas.org]. Xcaw12879 contains thirty effector genes of which twenty-six overlap with XccA306 (except pthA1, pthA2 and pthA3). Nineteen effectors are present in all four sequenced citrus canker causing variants compared (XccA, Xcaw, XauB, and XauC) and thus represent the core effector set for Xanthomonas that cause citrus canker. It is noteworthy that Escalon et al. [21] define a 'common repertoire' of 26 T3S effector genes present in 55 Xcc strains from several locations around the world. They did not use data from XauB and XauC in compiling this common repertoire which explains why 26 T3S effectors were identified previously [21] whereas we only identified 19 common T3S effectors. The effector genes avrBs2, хорK, xopL, $x o p Q, x o p R$, $x o p X$ and $x o p Z$ are found in all other sequenced Xanthomonas genomes and hence these seven genes might be a core set of effectors required for phytopathogenicity as suggested by Moreira et al. [10]. Twelve effector genes $(x o p A, x o p E 1, x o p E 3$, pthA4 or its functional homologs, xopI, xopV, xоpAD, xopAI, xоpAK, xоpAP, $h p a A$, and $h r p W$ ) are present in all four citrus canker causing variants (Xcaw, XccA, XauB and $\mathrm{XauC}$ ). Of the twelve effector genes, xopE3 and xopAI are present in Xcaw12879 albeit in different locations as compared to the potential genomic island in the other three strains causing citrus canker. However they may play a role in citrus canker as suggested by Moreira et al. [10]. Two effector genes avrGf1 and $x o p A F$ were identified in Xcaw, XauB and XauC but were not present in XccA306 genome (Table 1).

Multiple genes clustered into ten groups were identified in Xcaw12879 but not in XccA306 (Table 2). Many genes of these clusters present in Xcaw12879 but not in XccA306 have homologs in other Xanthomonas species. All these regions contain transposase, integrase or phage related genes indicating possible acquisition by horizontal gene transfer. An interesting difference noted in the above-mentioned regions is in cluster 5, which encodes for lipopolysaccharide (LPS) biosynthetic pathway. Interestingly, the LPS cluster in Xcaw12879 contains regions orthologous to both XccA306 and X. oryzae pv. oryzicola BLS256 as shown in Figure 3, which indicates that there has been horizontal gene transfer. Cluster 4 is almost $100 \mathrm{~kb}$ long and parts of cluster 4 are syntenic with regions from $X$. campestris pv. campestris 8004, a black spot pathogen of cabbage (Table 2). A MUMmer comparison between cluster 4 and $X$. campestris pv. campestris 8004 shows high synteny (Additional file 2). Three transcriptional regulators (XCAW_01037, XC AW_01129, XCAW_01131) and one two-component system (TCS) sensor kinase (XCAW_01148) and its 
Table 1 Effector repertoire of $X$. citri subsp. citri $A^{\mathrm{w}} 12879$ (Xcaw12879), X. citri subsp. citri str. 306 (XccA306), X. fuscans subsp. aurantifolii str. ICPB 11122 (XauB) and X. fuscans subsp. aurantifolii str. ICPB 10535 (XauC)

\begin{tabular}{|c|c|c|c|c|c|c|}
\hline Effector class & Xcaw12879 & ХccA306 & XauB & XauC & Pfam domains & References \\
\hline AvrBs2 & XCAW_00465 & XAC0076 & XAUB_16770 & XAUC_23650 & $\begin{array}{l}\text { Glycerophosphoryl diester } \\
\text { phosphodiesterase }\end{array}$ & {$[22]$} \\
\hline \multirow[t]{4}{*}{ PthA (AvrBs3, TAL) } & $\begin{array}{l}\text { XCAW_b00018 } \\
\text { (PthAw1) }\end{array}$ & $\begin{array}{l}\text { XACa0022 } \\
\text { (PthA1) }\end{array}$ & XAUB_40130 & XAUC_22430 & $\begin{array}{l}\text { Transcriptional activator, nuclear } \\
\text { localization }\end{array}$ & {$[23]$} \\
\hline & & $\begin{array}{l}\text { XACa0039 } \\
\text { (PthA2) }\end{array}$ & & XAUC_24060 & & \\
\hline & $\begin{array}{l}\text { XCAW_b00026 } \\
\text { (pthAw2) }\end{array}$ & $\begin{array}{l}\text { XACb0015 } \\
\text { (PthA3) }\end{array}$ & XAUB_28490 & XAUC_09900 & & \\
\hline & & $\begin{array}{l}\text { XACb0065 } \\
\text { (PthA4) }\end{array}$ & & XAUC_43080 & & \\
\hline $\begin{array}{c}\text { XopA (Hpa1/ } \\
\text { HpaG) }\end{array}$ & XCAW_00826 & XAC0416 & XAUB_19280 & XAUC_43660 & - & [24] \\
\hline XopE1 (AvrXacE1) & XCAW_00686 & XAC0286 & XAUB_37010 & XAUC_37580 & Putative transglutaminase & {$[25]$} \\
\hline XopE3 (AvrXacE2) & XCAW_03515 & XAC3224 & XAUB_14680 & XAUC_00040 & Putative transglutaminase & {$[26]$} \\
\hline XopF2 & XCAW_01384 & XAC2785 $\psi$ & XAUB_07540廿 & XAUC_21000\% & - & [27] \\
\hline Xopl & XCAW_03828 & XAC0754 & XAUB_39080 & XAUC_07100 & F-box protein & {$[28]$} \\
\hline XopK & XCAW_03372 & XAC3085 & XAUB_34090 & XAUC_12520 & - & [29] \\
\hline XopL & XCAW_03376 & XАC3090 & XAUB_34130 & $\begin{array}{l}\text { XAUC_02900/ } \\
\text { XAUC_124884 }\end{array}$ & LRR protein & {$[30]$} \\
\hline XopQ & XCAW_04706 & XAC4333 & XAUB_10220 & XAUC_14670 & $\begin{array}{l}\text { Inosine uridine nucleoside } \mathrm{N} \text { - } \\
\text { ribohydrolase }\end{array}$ & {$[27]$} \\
\hline XopR & XCAW_00677 & XAC0277 & XAUB_36920 & XAUC_37490 & - & [29] \\
\hline XopV & XCAW_03980 & XAC0601 & XAUB_23140 & XAUC_21260 & - & [29] \\
\hline XopX & XCAW_00956 & XAC0543 & XAUB_14760 & XAUC_20690 & - & {$[31]$} \\
\hline XopZ1 & XCAW_01815 & XAC2009 & $\begin{array}{l}\text { XAUB_11532/ } \\
\text { XAUB_137104 }\end{array}$ & XAUC_25915 & - & {$[26]$} \\
\hline XopAD & XCAW_00082 & XAC4213 & XAUB_02510 & XAUC_34870 & SKWP repeat protein & {$[32,33]$} \\
\hline XopAl & XCAW_01099 & XAC3230 & XAUB_26830 & XAUC_23780 & Putative ADP- ribosyltransferase & {$[34]$} \\
\hline XopAK & XCAW_04369 & XAC3666 & XAUB_02580 & XAUC_32490 & - & [33] \\
\hline XopAP & XCAW_03269 & XAC2990 & XAUB_13980 & XAUC_08760 & - & {$[35]$} \\
\hline HpaA & XCAW_00810 & XAC0400 & XAUB_19430 & XAUC_19990 & T3S control protein & {$[36]$} \\
\hline HrpW (PopW) & XCAW_03200 & XAC2922 & XAUB_19460 & XAUC_20020 & Pectate Lyase & {$[37]$} \\
\hline XopAQ & XCAW_03514 & $\begin{array}{c}\text { Not } \\
\text { annotated* }\end{array}$ & Not annotated ${ }^{* *}$ & - & - & {$[35]$} \\
\hline $\begin{array}{l}\text { XopE2 (AvrXacE3, } \\
\text { AvrXccE1) }\end{array}$ & XCAW_03520 & XACb0011 & XAUB_31660 & - & Putative transglutaminase & {$[25]$} \\
\hline XopN & XCAW_01387 & XAC2786 & XAUB_07520 & - & ARM/HEAT repeat & {$[38]$} \\
\hline XopP & XCAW_01310 & XAC1208 & XAUB_06720 & - & - & [27] \\
\hline $\begin{array}{l}\text { XopAE (HpaF/ } \\
\text { HpaG) }\end{array}$ & XCAW_00801 & XAC0393 & XAUB_19500 & - & LRR protein & [39] \\
\hline XopC2 & XCAW_01311 & $\begin{array}{l}\text { XAC1209/ } \\
\text { XAC12104 }\end{array}$ & & & Haloacid dehalogenase-like hydrolase & {$[39]$} \\
\hline XopAF (AvrXv3) & XCAW_b00003 & - & XAUB_02310 & XAUC_00300 & - & {$[40]$} \\
\hline $\begin{array}{l}\text { XopAG (AvrGf1/ } \\
\text { AvrGf2) }\end{array}$ & XCAW_00608 & - & XAUB_03570 $\psi$ & XAUC_04910 & - & [7] \\
\hline XopF1(Hpa4) & $\begin{array}{l}\text { XCAW_00804/ } \\
\text { XCAW_00805\% }\end{array}$ & - & & XAUC_317304 & & {$[30]$} \\
\hline
\end{tabular}


Table 1 Effector repertoire of $X$. citri subsp. citri $\mathrm{A}^{\mathrm{w}} 12879$ (Xcaw12879), X. citri subsp. citri str. 306 (XccA306), X. fuscans subsp. aurantifolii str. ICPB 11122 (XauB) and X. fuscans subsp. aurantifolii str. ICPB 10535 (XauC) (Continued)

\begin{tabular}{|c|c|c|c|c|c|c|}
\hline XopB & - & - & $\begin{array}{l}\text { XAUB_09070/ } \\
\text { XAUB_14842 } \psi\end{array}$ & XAUC_00260 & - & [41] \\
\hline XopE4 & - & - & XAUB_23330 & XAUC_31730 & Putative transglutaminase & [10] \\
\hline XopJ1 & - & - & XAUB_20830 & XAUC_08850 & $\begin{array}{c}\text { C55-family cysteine protease or Ser/ } \\
\text { Thr acetyltransferase }\end{array}$ & [27] \\
\hline
\end{tabular}

$\Psi$ Inactive/Pseudogene.

* Located between XAC3223 and XAC3224 from 3,797,415 bp to 3,797,702 bp.

** Located between XAUB_14670 \& XAUB_14680 on NZ_ACPX01000163 from 23,262 bp to 23,549 bp.

response regulator (XCAW_01150) are present in Xcaw12879, but are absent in XccA306.

\section{PthA and homologs}

All the citrus canker causing variants (XccA, Xcaw, $\mathrm{XccA}^{*}, \mathrm{XauB}$, and $\mathrm{XauC}$ ) contain PthA or its functional homologs. Thus, PthA or its functional homologs is likely the pathogenicity determinant of citrus canker pathogen as suggested in a previous study [17] that linked the strains of Xanthomonas with different host range together. Al-Saadi et al. [17] have shown that all the variants carry one $p t h A$ homolog with 17.5 repeats which determines pathogenicity on citrus and triggers immunity in various other plant species [42]. The avrBs3/pthA family of effectors includes various $p t h$ genes but only PthA [42] is known to induce canker. The functional homolog of this gene in XccA strain 306 is $p t h A 4$, which also has three other paralogs on its two plasmids (Table 1). We found two homologs pthAw1 and pthAw2 in Xcaw12879 genome, both located on plasmid pXcaw58. The pthAw2 gene is $99 \%$ identical to pthA4 from XccA and also to pthAw sequenced from another Wellington strain 0053 that is able to complement a knockout mutant of pthA in XccA strain 3213 [17], indicating that PthAw2 is the functional homolog of $p$ thA in Xcaw. PthAw2 has the same repeat number (17.5) as the functional homologs PthA4, PthB and PthC from the three respective citrus canker causing strains XccA, XauB, and XauC [10]. The other homolog PthAw1 in Xcaw has 18.5 tandem repeats, which is

Table 2 Gene clusters present in Xcaw12879 but absent in XccA306

\begin{tabular}{|c|c|c|c|}
\hline $\begin{array}{l}\text { Cluster } \\
\text { number }\end{array}$ & Locus tag & Homologs in other genomes & Function \\
\hline 1 & $\begin{array}{l}\text { XCAW_01029 to } \\
\text { XCAW_01069 }\end{array}$ & & $\begin{array}{l}\text { hypothetical proteins, RhsA family protein, transcriptional regulator, integrase, } \\
\text { adenine specific DNA methylase, type III restriction enzyme: res subunit, ATP } \\
\text { dependent exoDNAse, thermonulease }\end{array}$ \\
\hline 2 & $\begin{array}{l}\text { XCAW_01117 to } \\
\text { XCAW_01151 }\end{array}$ & $\begin{array}{l}\text { Some present in X. campestris pv. } \\
\text { campestris ATCC } 33913\end{array}$ & $\begin{array}{l}\text { transcriptional regulator, phage-related tail proteins, TCS response sensor and } \\
\text { regulator, chitinase, Zn peptidase, transcriptional repressor, protein -glutamate } \\
\text { methylesterase }\end{array}$ \\
\hline 3 & $\begin{array}{l}\text { XCAW_01571 to } \\
\text { XCAW_01582 }\end{array}$ & $\begin{array}{l}\text { Some present in } X \text {. campestris pv. } \\
\text { campestris str. } 8004\end{array}$ & phage related proteins, hypothetical protein \\
\hline 4 & $\begin{array}{l}\text { XCAW_01620 to } \\
\text { XCAW_01726 }\end{array}$ & $\begin{array}{l}\text { Homologous to Acidovorax sp. JS42 and } \\
\text { X. campestris pv. campestris str. } 8004\end{array}$ & $\begin{array}{l}\text { transposases, hypothetical proteins, type II restriction enzyme: methylase } \\
\text { subunit, phage related regulatory proteins, chromosome partitioning related } \\
\text { protein, soluble lytic murein transglycosylase, VirB6 protein }\end{array}$ \\
\hline 5 & $\begin{array}{l}\text { XCAW_04292 to } \\
\text { XCAW_04303 }\end{array}$ & $\begin{array}{l}\text { Homologous to X. oryzae pv. oryzicola } \\
\text { BLS256 }\end{array}$ & lipopolysaccharide biosynthesis genes \\
\hline 6 & $\begin{array}{l}\text { XCAW_04482 to } \\
\text { XCAW_04496 }\end{array}$ & & $\begin{array}{l}\text { transposases, hypothetical proteins, transcriptional repressor, polymerase } \mathrm{V} \\
\text { subunit }\end{array}$ \\
\hline 7 & $\begin{array}{l}\text { XCAW_04519 to } \\
\text { XCAW_04545 }\end{array}$ & $\begin{array}{l}\text { Homologous to X. oryzae pv. oryzae } \\
\text { PXO99A }\end{array}$ & $\begin{array}{l}\text { phage related proteins, transcriptional regulator, transposases, hypothetical } \\
\text { proteins }\end{array}$ \\
\hline 8 & $\begin{array}{l}\text { XCAW_a00001 } \\
\text { to } \\
\text { XCAW_a00017 }\end{array}$ & & Plasmid partition protein, conjugal transfer protein, hypothetical proteins \\
\hline 9 & $\begin{array}{l}\text { XCAW_b00002 } \\
\text { to } \\
\text { XACW_b00018 }\end{array}$ & & $\begin{array}{l}\text { Transposases, plasmid stability proteins, avirulence protein, hypothetical } \\
\text { proteins }\end{array}$ \\
\hline 10 & $\begin{array}{l}\text { XCAW_b00048 } \\
\text { to } \\
\text { XACW_b00056 }\end{array}$ & & Plasmid mobilization proteins, transposases, hypothetical proteins \\
\hline
\end{tabular}




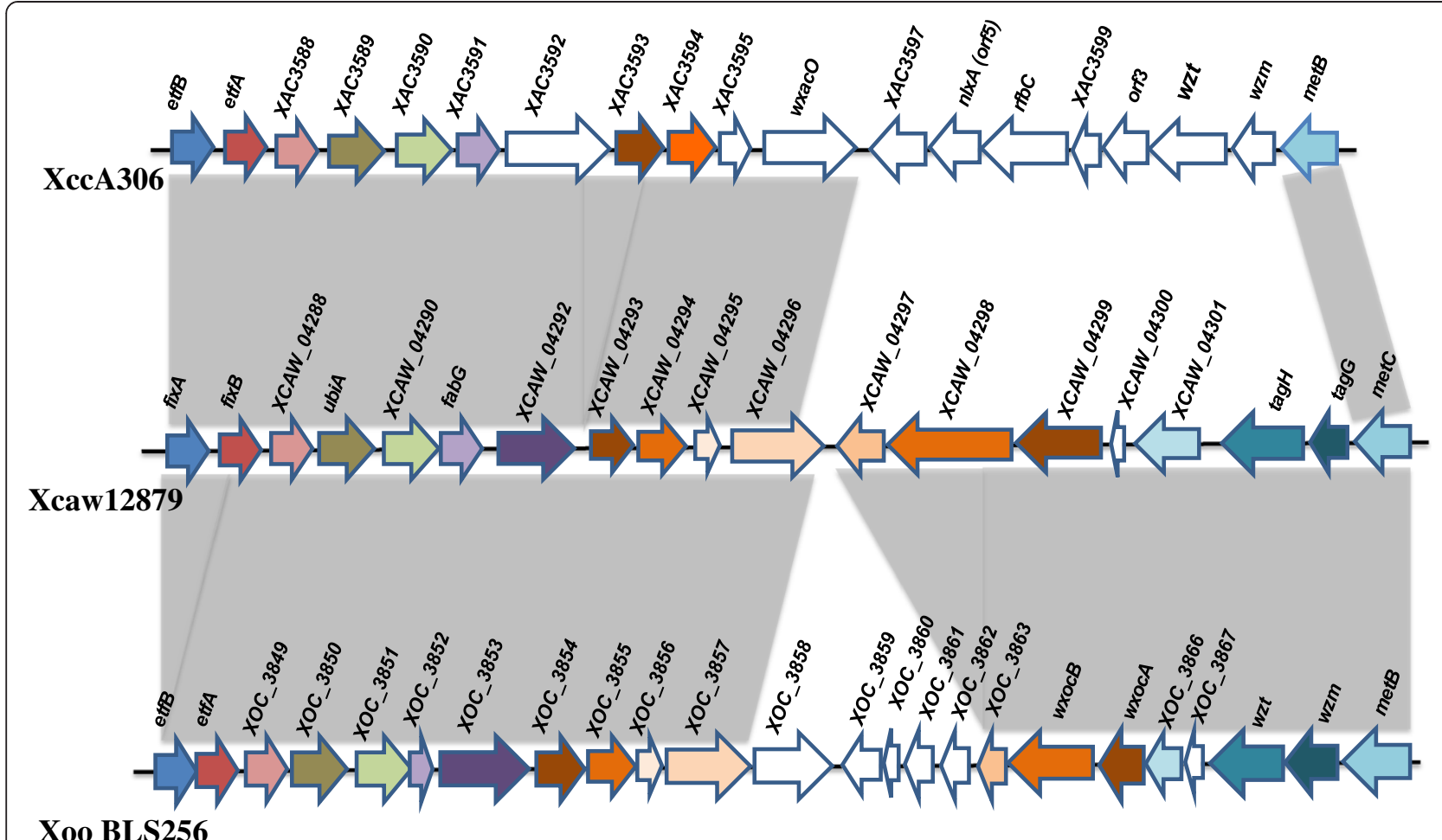

Figure 3 Comparison of the LPS gene clusters of $X$. citri subsp. citri str. $306, X$. citri subsp. citri $\mathrm{A}^{\mathrm{w}} 12879$ and $X$. oryzae pv. oryzicola str. BLS256. Conserved and highly related genes (over $80 \%$ identity) are colored and syntenic regions between the bacteria are shaded in grey (over $50 \%$ identity).

different from PthA homologs found in XccA that have either 15.5 or 16.5 tandem repeats. The AvrBs3/PthA family of effectors are known as transcription activatorlike (TAL) effectors since they reprogram host cells by specifically binding to the promoters of plant genes recognized by the central domain of tandem repeats [43]. Comparing the DNA binding TAL effector codes for PthA from XccA as predicted by Boch et al. [44] to PthAw indicate that the codes for PthA4 and PthAw2 are quite divergent (Additional file 3). Al-Saadi et al. [17] predicted that the well conserved sequence of the $17^{\text {th }}$ repeat in functional PthA might be important for pathogenicity on citrus, and this sequence is present in PthAw2. The rest of PthAw2 sequence however potentially encodes a DNA binding code that is only about $79 \%$ similar to the one encoded by PthA4 of XccA306 (Additional file 3). This may result in recognition of different target genes in host plant or differences in strength of induction of plant genes and thus affect virulence of Xcaw and XccA.

\section{Pathogenicity and growth assays}

All three host limited strains of Xanthomonas affecting citrus, Xcaw, XauB and XauC had avrGf1 and xopAF genes in their genomes. The gene avrGf1 has been previously studied in Xcaw and is known to be responsible for HR in grapefruit [7]. However its effect on other varieties of citrus such as sweet orange is unknown. Also, since $x o p A F$ is the other putative effector gene, its effect on host limitation was further characterized by pathogenicity and growth assays of Xcaw $\triangle x o p A F$ and Xcaw $\triangle a v r G f 1 \triangle x o p A F$.

Pathogenicity assays indicated that Xcaw12879 did not elicit any reaction on Valencia or Hamlin oranges at our test conditions while wild type XccA306 caused necrotic raised lesions, typical of citrus canker on the leaves at a high bacterial inoculation concentration of $10^{8} \mathrm{cfu} / \mathrm{ml}$ (Figure 4). Xcaw12879 showed a HR on grapefruit leaves that was abolished by deleting avrGf1 gene (Xcaw $\Delta$ avrGf1), however the growth of the mutant was visibly reduced compared to XccA306 strain. Xcaw $\Delta a v r G f 1$ did not show any symptoms or reaction on either Valencia or Hamlin (Figure 4).

To check whether mutation of xopAF affects Xcaw12879 growth in planta, the wild-type strains of XccA306 and Xcaw12879, Xcaw $\triangle x o p A F$, Xcaw $\triangle x o p A F-$ 53:xopAF (complementary strain), Xcaw $\triangle a v r G f 1$ and Xcaw $\Delta x o p A F \Delta a v r G f 1$ mutant strains were inoculated into grapefruit, Mexican lime and Valencia leaves. As shown in Figure 5A, the population of Xcaw12879 was much lower compared to XccA306 in grapefruit. This population of Xcaw $\Delta a v r G f 1$ was increased compared to the wild type 


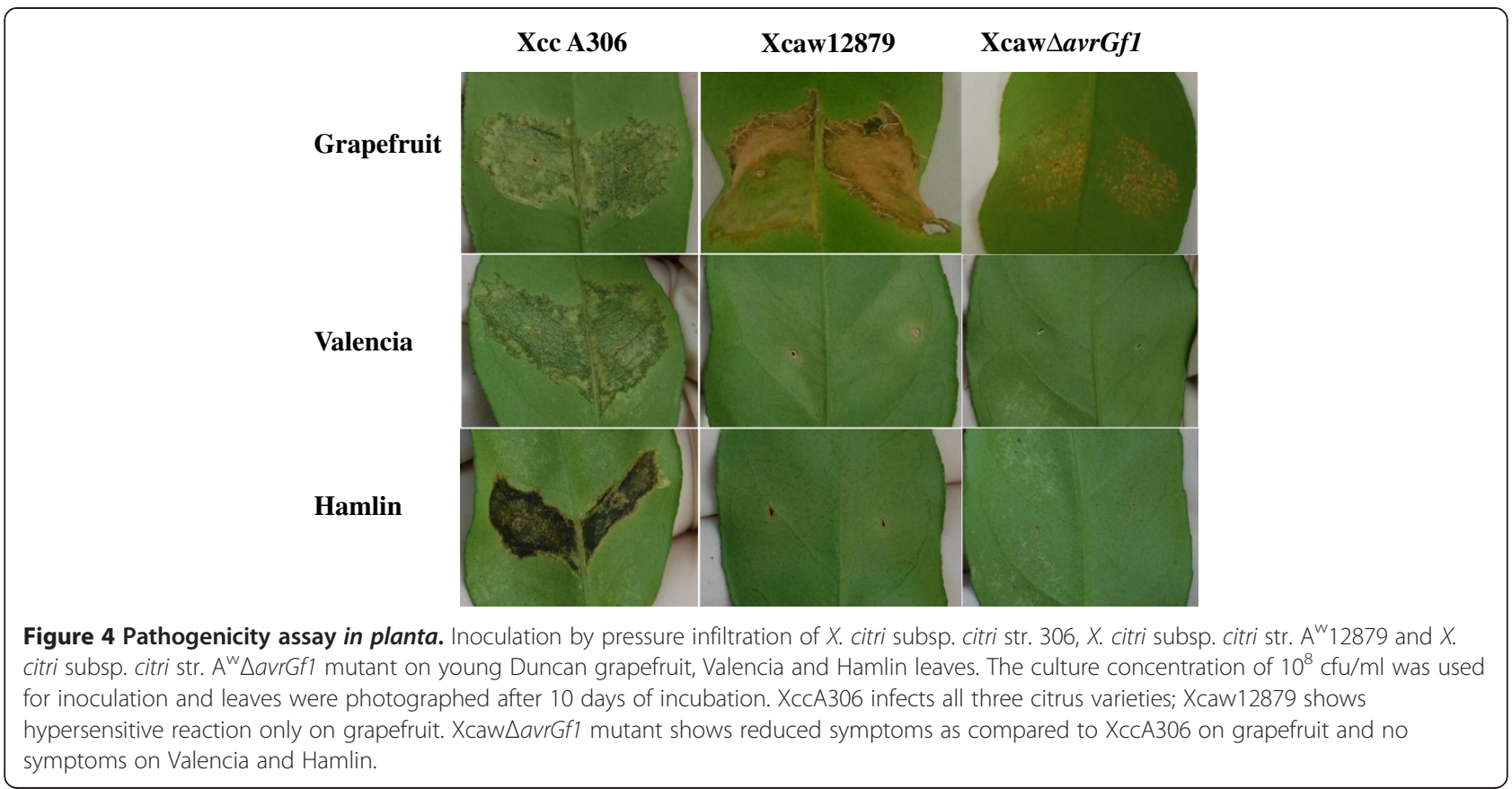

Xcaw12879 and Xcaw $\Delta a v r G f 1$ caused symptoms on grapefruit. However, the populations of Xcaw $\triangle x o p A F$ and Xcaw $\triangle x o p A F \Delta a v r G f 1$ mutants were one order magnitude lower than that of Xcaw12879 and Xcaw $\triangle a v r G f 1$ respectively, indicating that mutation of xopAF gene decreased the growth of Xcaw12879 in planta. A similar trend was observed in Mexican lime where the populations of xopAF single and $x o p A F$, avrGf1 double mutants were lower compared to Xcaw12879 and Xcaw $\Delta a v r G f 1$ respectively (Figure 5B). The growth of Xcaw $\triangle x o p A F$ in grapefruit and Mexican lime was restored to similar levels as Xcaw12879 by the complementation (Figure 5). No significant changes were observed in Valencia leaves as neither Xcaw12879 nor any of its mutants grew well in the sweet orange variety as compared to XccA306 (Figure 5C).

\section{Transcriptome analyses of Xcaw12879 and XccA306 under nutrient rich (NB) and hrp gene expression inducing (XVM2) conditions}

To determine the differential gene expression amongst the strains of $X$ citri subsp. citri, we grew Xcaw12879 and XccA306 under nutrient rich condition in Nutrient Broth (NB) and in XVM2 [12]. Three biological replicates of the strains were used for RNA-Seq. Over 45 million reads were obtained on average for each sample. After trimming and mapping, approximately $96 \%$ of the reads were mapped to the genomes (data not shown) indicating that RNA-Seq provides high quality reads suitable for Xanthomonas transcriptomics. Of all the reads, over 6.5 to 14 million reads could be mapped from each sample to mRNA specifically (Additional file 4). This gave an enrichment of mRNA from $11.3 \%$ up to $28.5 \%$ for each sample. It has been suggested that 5-10 million non-rRNA fragments enable profiling of the vast majority of transcriptional activity in diverse species including E. coli grown under diverse culture conditions [45]. It was also found that when RNA-Seq data from biological replicates is available, differential expression of numerous genes can be detected with high statistical significance even when the number of fragments per sample is reduced to 2-3 million [45]. Thus our RNA-Seq data is likely sufficient for the transcriptome analysis of XccA306 and Xcaw12879.

To quantify the expression of each gene, the reads aligned to each gene were pooled and normalized for gene size by calculating the Reads Per Kb per Million reads (RPKM) values. The values for each gene from all the replicates were further quantile normalized to test them statistically. The resulting values were $\log _{2}$ transformed and $t$-test was performed on these expression values to compare differential gene expression (DGE) between XccA306 and Xcaw12879 under the same growth conditions or between the same strains in NB or XVM2 growth conditions. High correlation was observed between differential expression values of biological replicates (Additional file 5), signifying that the method was reproducible. Principal component analysis indicates that the biological replicates of XccA formed a separate cluster from Xcaw in both growth conditions (Additional file 6).

qRT-PCR was used to validate the RNA-Seq data. Eight genes were chosen (Additional file 7) that were differentially expressed in Xcaw as compared to XccA under both NB and XVM2 growth conditions to compare data obtained from the two methods. The resulting 


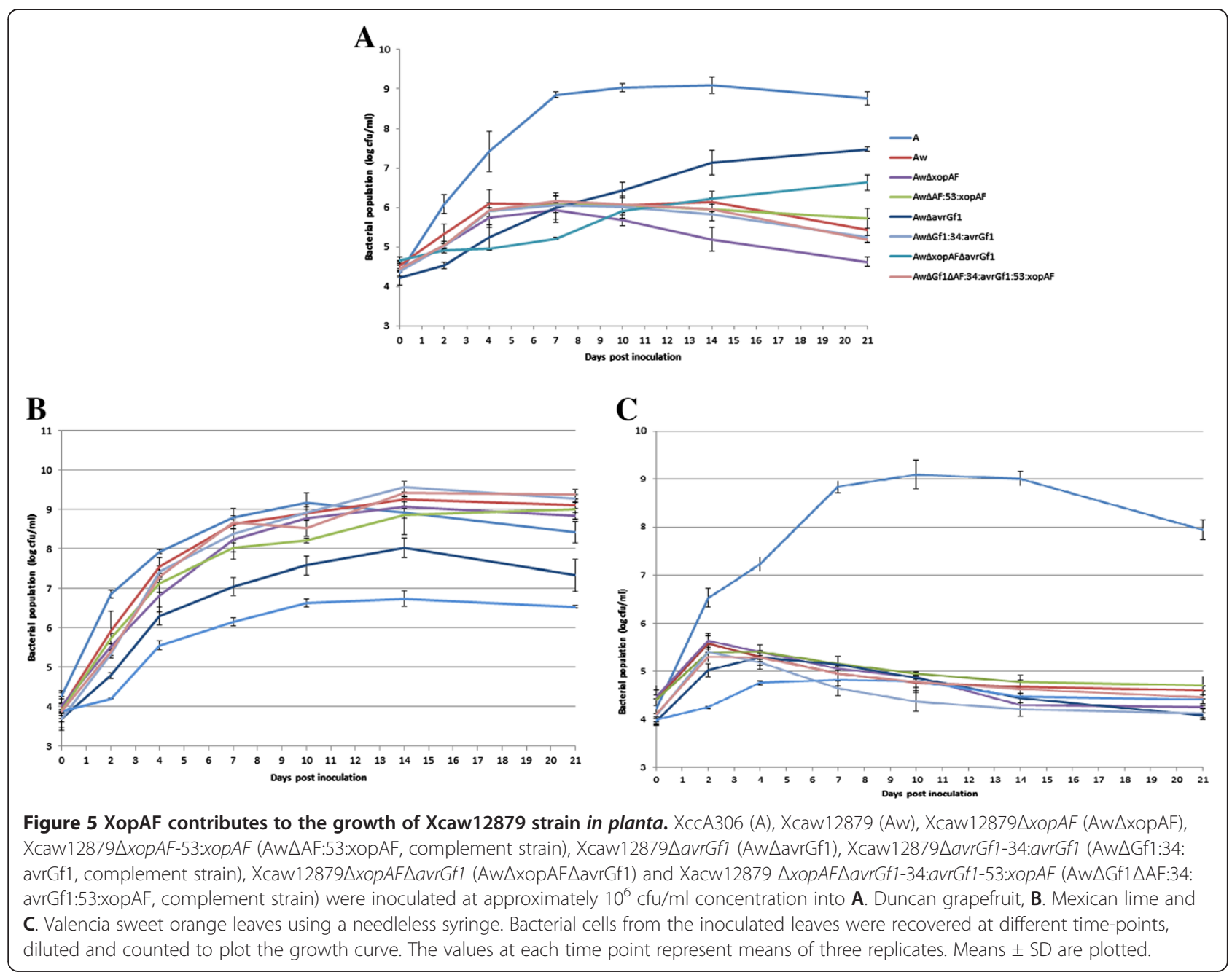

transcriptional ratio from $\mathrm{qRT}-\mathrm{PCR}$ analysis was $\log _{2}$ transformed to compare with the DGE values obtained by RNA-Seq (Additional file 8). Although the scale of fold changes between the two techniques is different, high correlation coefficient of 0.87 verifies that the general trend of gene expression is consistent for both data sets.

We studied the expression profile of Xcc strains in XVM2 as compared to NB. At the cut-off of | fold change $\mid=3, \mathrm{FDR}<0.05,292$ genes showed differential expression (173 up-regulated and 119 down-regulated in XVM2 compared to NB) in XccA (Additional file 9) and 281 genes (129 up-regulated and 152 down-regulated in XVM2 compared to NB) for Xcaw (Additional file 10). The entire T3SS cluster consisting of twenty-five genes except one gene (XAC0395) was up-regulated in XVM2 for both XccA and Xcaw strains (Additional files 9 and 10). Among all the effectors, sixteen were induced for XccA whereas nineteen effectors were overexpressed for Xcaw in XVM2 compared to in NB. As identified in this study, the effector genes avrBs2, xopA, xopE1, xоpE3,
xорI, хорХ, хорZ1, хорAD, хорAP, хорAQ, һраA, хорN and $x о p P$ were up-regulated in XVM2 in both strains, while pthA1, pthA2, avrXacE3 and xopK were induced only in XccA and xopL, xopR, xopAI, xopAK, xоpAF and $x o p A G$ only in Xcaw strain.

The 11-gene xps cluster encodes for type 2 secretion system (T2SS) in Xanthomonas secreting various enzymes including pectate lyase, cellulase, and xylanase. The xps genes were down-regulated in XVM2 as compared to in NB for Xcaw, with $x p s E$ being the most significantly down-regulated. For XccA, the xps genes were not down-regulated. Besides the T2SS genes, at least 22 genes encoding T2SS substrates in XccA were overexpressed in XVM2 as compared to only 12 in Xcaw. To the contrary 11 genes for Xcaw and 8 for XccA were down-regulated in XVM2 compared to in NB (Additional files 9 and 10).

Our analysis showed that all the flagella biosynthesis genes encoded by $f l g$ and $f l i$, motility by mot and chemotaxis by $m c p$, che and $t s r$ were repressed in XVM2 for XccA and Xcaw except cheY (XAC3284 in XccA and 
XCAW_03412 in Xcaw) and tar (XCAW_03417, XCAW_04009 and XCAW_02497). The genes encoding LPS were down-regulated in both Xcaw and XccA, whereas the xanthan gum (EPS) genes were overexpressed in both except gumP in XccA. A few genes encoding outer membrane proteins, which are involved in adhesion, including ompW, blc and hms were up-regulated in XVM2 as compared to in NB for both strains while $x a d A$ and $y a p H$ were induced in XccA but down-regulated in Xcaw. The Type IV pili genes encoded by pil and fim genes except pilB and filamentous haemagglutinin related genes (fhaB, $X A C 1816)$ were down-regulated in both Xcaw and XccA (Additional files 9 and 10).

In order to further understand the molecular mechanisms determining the differences in virulence and host range of Xcaw and XccA, we compared the expression profile of common genes of Xcaw and XccA. When expression of orthologous genes in Xcaw was compared to XccA, 603 genes (426 overexpressed and 177 down-regulated) in NB (Additional file 11) and 450 genes (319 overexpressed and 131 down-regulated) genes in XVM2 (Additional file 12) conditions were significantly differentially regulated at cut-off value of $\mid$ fold change $\mid=3$ and FDR $<0.05$. On comparing the differentially expressed genes in both conditions, 126 genes were differentially regulated in Xcaw as compared to XccA, irrespective of the growth conditions (Figure 6). Of these 87 were overexpressed in Xcaw and 39 genes were repressed as compared to XccA (Additional file 13). Of the 87 genes overexpressed in $\mathrm{Xcaw}, 35$ were virulence-related genes including $h r p X$, hrpG, phoP-phoQ regulatory genes, and T2SS substrate genes (XAC2537, XAC2763, XAC2999, XAC4004) (Additional file 13). Of the 39 genes overexpressed in XccA, 21 were virulence-related genes including cellulase genes (XAC0028, XAC0029 and engXCA), reactive oxygen species scavenging enzyme genes, e.g., superoxide dismutase gene sodC2, and genes encoding heat shock protein GrpE and heat stress protein Muc.

Since the gene expression of T2SS substrate genes was different, we compared the protease and pectate lyase activities of XccA306 and Xcaw12879. Xcaw12879 showed higher protease activity than XccA306 (Figure 7A). Xcaw12879 showed lower pectate lyase activity compared to XccA306 (Figure 7B).

\section{Discussion}

Comparative analysis of Xcaw12879 and XccA306 identified multiple strain-specific genes that might contribute to the differences in virulence and host range. Among the genes present in Xcaw12879, but absent in XccA306, two effector genes xopAG (avrGf1) and xopAF were identified in Xcaw, XauB and XauC but were not present in XccA306 genome (Table 1). The presence of these effectors in limited host range strains causing citrus canker and not in the broader host range XccA306 makes them prime candidates for effectors that could affect host specificity. Importantly, the role of xopAG (avrGf1) in limiting the host range of Xcaw has been confirmed previously [7]. The xopAG gene belongs to the avrGf1 family and has been shown to trigger HR in grapefruit [7]. AvrGf1 in Xcaw shows only about $45 \%$ identity to its homolog XAUC_04910 in XauC whereas the homolog XAUB_03570 in XauB is interrupted by a transposon and might be non-functional, which probably contributes to the broader host range of $\mathrm{XauB}$ compared to $\mathrm{Xcaw}$ and $\mathrm{XauC}[2,3]$. When the mutant Xcaw $\Delta x o p A G$ was inoculated in grapefruit it caused typical canker like symptoms instead of HR, but the symptoms were visibly reduced [7]. Also, Xcaw $\Delta a v r G f 1$ does not cause disease

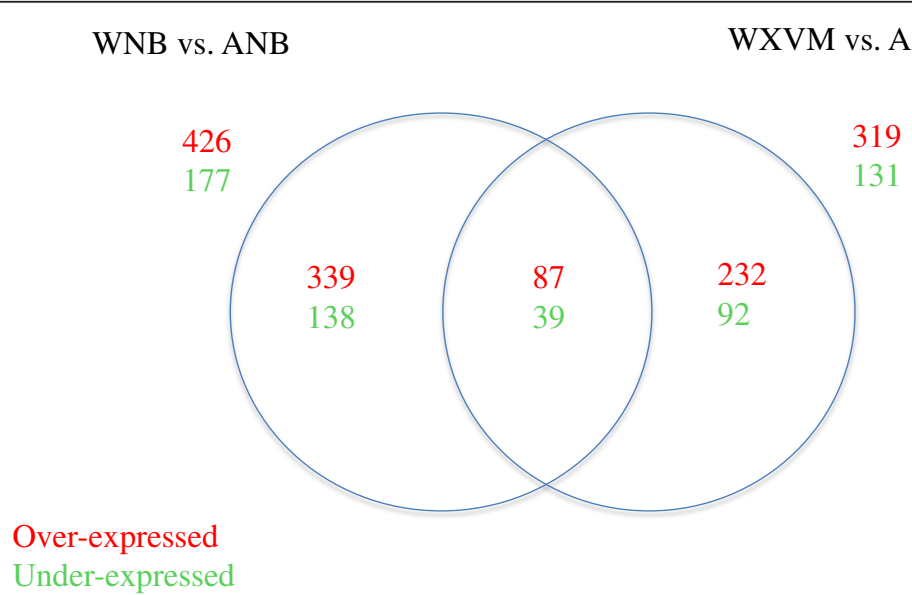

Figure 6 Number of differentially expressed genes when comparing expression of common genes in $X$. citri subsp. citri str. $\mathrm{A}^{\mathrm{w}} 12879$ to $X$. citri subsp. citri str. 306 in NB and XVM2 growth conditions. Gene expression of orthologous genes between Xcaw (W) and XccA (A) was compared when grown in Nutrient broth (NB, nutrient rich medium) and XVM2 (XVM, hrp inducing medium). 

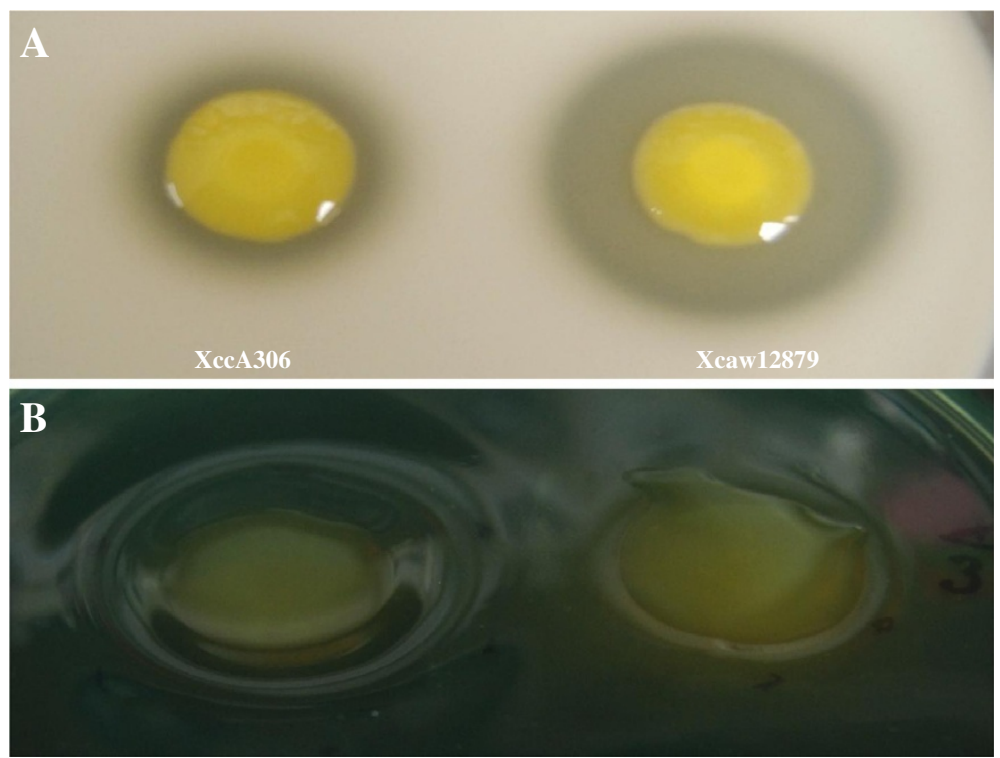

Figure 7 Protease and Pectate lyase activity of $X$. citri subsp. citri str. 306, and $X$. citri subsp. citri str. $A^{\mathrm{w}} 12879$. (A) Protease activity was tested by inoculating $1 \mu \mathrm{l}$ culture on $10 \%$ milk agar plates at $28^{\circ} \mathrm{C}$ for 6 days. Zone of clearance was used as the measure of protease activity. (B) Pectate lyase activity was tested by inoculating $1 \mu \mathrm{l}$ culture on Hildebrand's agar medium at $28^{\circ} \mathrm{C}$ for 6 days. More pitting can be seen on medium at $\mathrm{pH} 8.5$ for XccA strain compared to Xcaw.

on sweet orange (Valencia and Hamlin) as shown in Figure 4, indicating that there are other host limiting factors in the Xcaw12879 genome or other virulence factors are required for XccA306 to infect different hosts. Another candidate gene, which might contribute to host specificity, is $x o p A F$, which belongs to avrXv3 family and is located on the plasmid pXcaw58 in Xcaw12879. Homologs of xopAF, XAUB_02310 and XAUC_00300 are found in XauB and XauC but not in XccA306 (Table 1). Thus, we initially hypothesized that XopAF may contribute to restricting host range of Xcaw12879, XauB, and $\mathrm{XauC}$ to limited varieties of citrus as compared to XccA306. Additionally, an xopAF homolog avrXv3 from $X$. campestris pv. vesicatoria is known to induce HR in tomato line Hawaii 7981 and pepper plants [40]. The same work also ascertained that the gene was plant inducible and regulated by the $h r p$ regulatory system. The $\mathrm{C}$ terminal region of the protein encodes for a putative transcription activator domain indicating that it might interact with plant host genes. In this study we found that xopAF mutant and xopAF avrGF1 double mutant both have lower growth in planta as compared to Xcaw12879 and avrGF1 single mutant respectively (Figure 5). Mutation of xopAF did not make Xcaw12879 strain pathogenic in sweet orange Valencia. Instead, mutation of $x o p A F$ slowed the growth of the pathogen in grapefruit and Mexican lime, which was restored by complementation, indicating that XopAF is important for bacterial growth in planta. In addition to the effectors documented above, other effectors that differ in their presence are $x o p A Q, x o p E 2, x o p N, x o p P$ and $x o p A E$, present in Xcaw12879, XccA306 and XauB but not in XauC strain. Also $x о p B, x o p E 4$ and $x о p J 1$ are present in both $\mathrm{XauB}$ and $\mathrm{XauC}$ but missing from XccA306 and Xcaw12879. How these effectors contribute to virulence and host range of XccA, Xcaw, XauB, and $\mathrm{XauC}$ requires further investigation.

Other gene content differences between Xcaw12879 and XccA306 include differences in LPS cluster (Figure 3), phage related genes with Xcaw containing XCAW_1134 to XCAW_1142, XACW_4520 to XCAW_4227 whereas XccA exclusively includes XAC1063, XAC2628, and Type IV secretion system and a plant-like natriuretic peptide (PNP) encoding gene (XAC2654). Interestingly, all the genes in LPS cluster from Xcaw12879 show high similarity with LPS region from rice pathogen $X$. oryzae pv. oryzicola BLS256, whereas only approximately half the cluster is syntenic to XccA306 LPS cluster (Figure 3). This suggests that HGT has probably resulted in a hybrid LPS cluster in Xcaw12879 similar to X. oryzae pv. oryzicola BLS256 [46]. LPS, phage related proteins, type IV secretion system and PNP have been reported to play certain roles in virulence [18,47-51]. How they contribute to the difference of Xcaw and XccA in virulence and host range remains to be investigated experimentally.

Virulence related genes were differentially regulated in XVM2 as compared to NB for both Xcaw12879 and XccA306. In XccA306 (Additional file 9), fifty-nine virulence related genes were induced and thirty-eight genes were repressed in XVM2 compared to NB. In 
Xcaw12879 (Additional file 10), forty virulence related genes were induced and twenty-four genes were repressed in XVM2 compared to NB. The induction of the virulence genes in XVM2 condition compared to nutrient rich NB is supported by a previous study [52]. In the previous study, only 279 genes of XccA potentially associated with pathogenicity and virulence were tested and 31 genes were up-regulated in XVM2, while only 7 genes were repressed. In our study, we further expanded the previous study by including all genes of XccA and provided a comprehensive picture of Xanthomonas gene regulation.

The entire T3SS cluster consisting of twenty-five genes except one (XAC0395) was up-regulated in XVM2 for both XccA and Xcaw strains. This is consistent with previous report that Xanthomonas hrp genes were induced in XVM2 [52,53]. However, only eight hrp genes of XccA were reported to be up-regulated by XVM2 in the previous study [52] compared to 24 induced hrp genes identified in this study. Among all the effectors, 16 were induced for XccA whereas 19 effectors were overexpressed for Xcaw in XVM2. In the previous study [52], only three effector genes avrXacE1, avrXacE2, and Xac0076 of XccA were induced in XVM2. Thus, our study further expanded the knowledge of expression of the hrp and effector genes in XVM2 medium.

Interestingly, both $h r p X$ and $h r p G$ genes were overexpressed in the Xcaw compared to XccA (Additional file 13). Both genes have been shown to be critical for virulence in Xanthomonas spp. [54]. The $h r p X$ gene encodes an AraC-type transcriptional activator and $h r p G$ gene encodes an OmpR family regulator, which are known to regulate many virulence related genes including T3SS effectors, T2SS substrate, flagella, and chemotaxis genes [55]. Overexpression of Xcaw $h r p G$ in $X$. perforans elicited HR in grapefruit and Mexican lime leaves probably by inducing xop $A$ and other avirulence genes [7]. The xop $A$ gene encodes harpin and was suggested to be a host-limiting factor by inducing HR. Its homologues $h p a G$ and $h r p N$ are also known to induce HR. However, the xopA gene was not overexpressed significantly in Xcaw compared to XccA (Additional file 14). The fold change of xopA was more than 2, but the FDR did not pass the cut off value. Five other effector genes xopL, xоpX, xорAD, $h r p W$, and $x o p A Q$ were overexpressed in Xcaw in $X V M 2$, whereas only one effector gene $x o p A P$ was induced in XccA in NB (Additional file 14). Overexpression of those effector genes in Xcaw might contribute to the limited host range of Xcaw. In addition, the phoP-phoQ two component system genes were overexpressed in Xcaw compared to XccA (Additional file 13). The phoP gene encoding a response regulator is predicted to interact with various signal sensor proteins in addition to PhoQ. It is known to activate the response regulator $h r p G$ in $X$. oryzae pv. oryzae, thus leading to activation of various virulence and growth factor genes downstream [56]. The $p h o Q$ gene on the other hand is required for the activity of AvrXA21 in X. oryzae pv. oryzae, which determines host-variation of the strain against some rice lines [56]. Thus in Xcaw, overexpression of phoP-phoQ could contribute to activation of certain effector genes mentioned above.

T2SS is the major protein secretion system, which secretes toxins and various degradative enzymes to breakdown the cell wall in plant hosts [20]. T2SS and its substrates have been shown to be important for the virulence of XccA [57]. The xps genes were down-regulated in XVM2 as compared to in NB for Xcaw with $x p s E$ being the most significantly down-regulated (Additional file 10). XpsE is known to be a key component of T2SS, the loss of which leads to lower virulence in $X$. oryzae [4]. For XccA, the xps genes were not down-regulated. Down-regulation of xps genes in Xcaw but not in XccA might contribute to differences in virulence on different hosts of Xcaw and XccA. In XccA at least 22 genes encoding T2SS substrates were overexpressed as compared to only 12 in Xcaw. On the contrary 11 genes for Xcaw and 8 for XccA were down-regulated. This is similar to the previous study where genes encoding T2SS substrates were found either down-regulated or up-regulated in XVM2 [52]. Specifically, four T2SS substrate protease genes (XAC2537, XAC2763, XAC2999, and XAC4004) were up-regulated in Xcaw compared to XccA in both conditions (Additional file 13). Consequently, Xcaw showed higher protease activity than XccA (Figure 7A). In contrast, multiple cellulase genes (XAC0028, XAC0029, and engXCA) were downregulated in Xcaw compared to XccA (Additional file 13). Pectate lyase gene pel (XAC03562) was also downregulated in Xcaw compared to XccA in NB medium (Additional file 11). Consequently, Xcaw showed lower pectate lyase activity as compared to XccA (Figure 7B). Thus, the protease and pectate lyase activities are consistent with the differential regulation of genes encoding T2SS substrates in Xcaw and XccA.

Compared to Xcaw, multiple virulence genes were overexpressed in XccA which might contribute to its adaption to a broad host range (Additional file 13). These include many reactive oxygen species-scavenging enzyme genes, e.g., sodC2 and grpE, which indicates that XccA might be more adapted to stressful conditions due to the host defense responses of different hosts. Attachment of Xanthomonas to plant cell surfaces is important for pathogenicity [58,59]. Multiple genes involved in adherence were overexpressed in XccA in NB medium (Additional file 11) including filamentous haemagglutinin gene fhaB, gum genes $($ gumB to gumK, gumM), chemotaxis genes (XAC0611, XAC1666, 
XAC1891, XAC1893, XAC1894, XAC1895, XAC1896, XAC1897, XAC1899, XAC1900, XAC1902), mcp genes (XAC1996, XAC2448, XAC2866, XAC3132), cheA (XAC2865), cheR (XAC1890), cheR (XAC2869), cheY (XAC1904) and cheD (XAC1889). Multiple transporter genes, which are known to play critical roles in bacteria to acquire nutrients from the intercellular environment, were overexpressed in XccA in XVM2 as compared to Xcaw, e.g., the potassium transporter genes $k d p B, k d p C$ and $k d p D$ and the iron siderophore transporter gene fhuA (XAC2185) and XAC2830 (Additional file 12). Altogether, they might contribute to the virulence on broad host of XccA as compared to Xcaw.

\section{Conclusions}

In conclusion, comparative genomic analysis of Xcaw12879, $\mathrm{XauB}, \mathrm{XauC}$, and XccA306 provides insights into the virulence mechanism of $X$. citri subsp. citri. Our study indicated that AvrGf1 mainly contributes to the host range limitation of Xcaw12879 whereas XopAF contributes to virulence. In addition, we compared the gene expression profiles of XccA306 and Xcaw12879 in NB and XVM2. Our data demonstrated that virulence genes including genes encoding T3SS and its effectors are induced in XVM2 medium. Numerous genes with differential expression in Xcaw12879 and XccA306 were identified. This study lays the foundation to further characterize the mechanisms for virulence and host range of strains of $X$. citri subsp. citri and other bacterial pathogens.

\section{Methods}

\section{Phylogenetic and comparative analysis}

The deduced protein sequences of nine housekeeping genes (uvrD, secA, carA, recA, groEL, dnaK, atpD, gyrB and $i n f B$ ) from 13 completely sequenced and $10 \mathrm{draft}$ Xanthomonas spp., and three Xylella fastidiosa strains (out-group species) were used to construct the phylogenetic tree. Amino acid sequences were aligned using ClustalW 2.1 [60]. A phylogenetic tree was constructed from the concatenated sequences using CLC Genomics Workbench v6.0 (CLC Bio, Aarhus, Denmark) by the maximum likelihood method. Comparative analyses of XccA306 and Xcaw12879 was conducted by, a two-way BLAST of the nucleotide sequences to identify unique genes in each strain using the standalone blast + software (ncbi-blast-2.2.4). The genes were considered orthologous if reciprocal TBLASTN hits were found between two genes with e-value less than or equal to $10^{-10}$ and alignments exceeding $60 \%$ sequence identity and $60 \%$ query gene length. A gene was considered singleton or unique to each strain if it had no hits or with an $e$-values less than or equal to $10^{-5}[61,62]$. The CRISPRfinder server [63] was used to identify CRISPRs. Only confirmed structures are reported here. Alignment between whole chromosomes was done using the script Promer from the MUMmer package [64]. Promer does alignments between translated nucleotide sequences.

\section{Preparation of RNA samples for transcriptome analysis}

RNA sample preparation and cDNA library generation were performed according to procedures outlined by Filiatrault et al. [65] with some modifications. RNA samples were extracted from XccA306 and Xcaw12879 grown to $\mathrm{OD}_{600}$ of 0.4 in XVM2 medium and $\mathrm{NB}$ medium at $28^{\circ} \mathrm{C}$ on shaker at $200 \mathrm{rpm}$. The starting $\mathrm{OD}_{600}$ for each culture was 0.03. Three biological replicates of each strain in each medium were used for RNA extraction. When the $\mathrm{OD}_{560}$ reached 0.4 for each condition, RNA was stabilized immediately by mixing 10 $\mathrm{ml}$ of the culture with two volumes of RNAprotect bacterial reagent (Qiagen, Valencia, CA). The cells were centrifuged at $5000 \times \mathrm{g}$ at $4^{\circ} \mathrm{C}$ and cell pellets were treated with lysozyme and RNA extractions were performed using RiboPure bacteria kit (Ambion, Austin, TX) per manufacturers" instructions. Genomic DNA was removed by treatment with TURBO DNA-free kit (Ambion, Austin, TX). Total RNA samples were quantified using spectrophotometry (Nanodrop ND-1000, NanoDrop Tech. Inc.). RNA quality was assessed using the Agilent 2100 bioanalyzer (Agilent Technologies, Palo Alto, CA).

\section{MRNA enrichment and library construction}

mRNA was enriched from total RNA using MicrobExpress kit (Ambion) to remove the $23 \mathrm{~S}$ and $16 \mathrm{~S}$ ribosomal RNAs (rRNAs). Removal of rRNAs was assessed using an Agilent Bioanalyzer. Double stranded cDNA synthesis was performed following the Illumina mRNA Sequencing sample preparation guide (Cat. No. RS-930-1001) in accordance with the manufacturer's standard protocol. Enriched mRNA was fragmented via incubation for $5 \mathrm{~min}$ at $94^{\circ} \mathrm{C}$ with the Illumina-supplied fragmentation buffer. The first strand of cDNA was synthesized by reverse transcription using random oligo primers. Second-strand synthesis was conducted by incubation with RNAse $\mathrm{H}$ and DNA polymerase I. The resulting dsDNA fragments were further end-repaired, and A-nucleotide overhangs were added. After the ligation of Illumina adaptors, the samples were run on a denaturing gel and the band correlating to 200 $( \pm 25)$ base pairs on the denatured DNA ladder was selected. The selected DNA constructs were amplified by PCR using the primers provided in the Illumina library kit. The amplified constructs were purified and the library was validated using Agilent 2100 bioanalyzer.

\section{Illumina sequencing and alignment}

Paired-end, 75-cycle sequencing of the libraries was performed using an Illumina GAIIx at Yale Center for 
Genomic Analysis. The raw sequencing reads were further analyzed using CLC Genomics Workbench v6.0 (CLC Bio, Aarhus, Denmark). The reads were trimmed using the quality score limit of 0.08 and maximum limit of 2 ambiguous nucleotides. The trimmed reads were mapped to the genome and the protein-coding genes of XccA306 (GenBank accession no. NC_003919, NC_003921.3 and NC_003922.1) and Xcaw12879, with the parameters allowing mapping of reads to the genome with up to 2 mismatches. The reads mapped to rRNA and the reads not uniquely mapped were removed from further analysis. The expression levels were evaluated by RPKM method as described by Mortazavi et al. [66].

\section{Differential gene expression analysis}

The differential gene expression of the pooled samples from each condition was analyzed using CLC Genomics Workbench v6.0 (CLC Bio, Aarhus, Denmark). RPKM values were normalized using quantile normalization and further $\log _{2}$ transformed for statistical analysis. Box plots, hierarchical clustering of samples and principal component analysis were done to examine data quality and comparability. A $t$-test was performed on $\log _{2^{-}}$ transformed data to identify the genes with significant changes in expression between the two growth conditions and between the two strains. The $p$-values were adjusted for the false discovery rate (FDR) using the Benjamini and Hochberg method [67].

\section{Quantitative reverse transcription - PCR (qRT-PCR)}

To verify the RNA-Seq result, qRT-PCR assays were carried out using the same sets of RNA for RNA-Seq analysis. Gene specific primers listed in Additional file 7 were designed to generate sequences of 100-250 bp in length from the XccA306 genome. qRT-PCR was performed for all 3 biological replicates of XccA306 and Xcaw12879 grown in NB and XVM2 on a 7500 fast real-time PCR system (Applied Biosystems) using QuantiTect $^{\text {TM }}$ SYBR $^{\oplus}$ Green RT-PCR kit (Qiagen) following the manufacturers' instructions. $16 \mathrm{~S}$ rRNA was used as an endogenous control. The fold change of gene expression was calculated by using the formula $2_{\mathrm{T}}^{-\Delta \Delta \mathrm{C}}$ [68]. The fold change was further $\log _{2}$ transformed to compare with the RNA-Seq data.

\section{Generation of the xopAF mutant and xopAF, avrGf1 double mutant}

To construct the xopAF deletion mutant, the 1096-bp fragment containing entire $x o p A F$ gene was amplified using genomic DNA of Xcaw12879 as template and primers xopAFF1 and xopAFR. This resulted in F1, containing a $B a m \mathrm{HI}$ restriction site within the $x o p A F$ gene. A 422 bp fragment containing 337 bp of xopAF gene and its downstream region was amplified further from F1 using primers xopAFF2-BamHI and xopAFR (Additional file 7), resulting in F2. Both F1 and F2 were digested with BamHI and fragments F3 (414 bp) and F4 (500 bp) were gel purified. The fragments were ligated and cloned into pGEM-T easy vector, resulting in the construct named pGEM- $\triangle x o p A F$ that was confirmed by PCR and sequencing. From pGEM- $\triangle x o p A F$, an ApaIPstI fragment containing xopAF gene with 192 bp internal deletion was transferred into ApaI-PstI digested suicide vector pNTPS138, resulting in pNTPS- $\triangle x o p A F$. The construct pNTPS- $\triangle x o p A F$ was transformed into $E$. coli DH5 $\alpha \lambda$ PIR. The construct was purified from E. coli and subsequently transferred into Xcaw12879 and Xcaw12879 $\Delta a v r G f 1$ generated in a previous study [7] by electroporation. Transformants were selected on NA medium supplemented with $50 \mu \mathrm{g} / \mu \mathrm{l}$ kanamycin. Positive colonies were replicated on both NA plates supplemented with $5 \%(\mathrm{w} / \mathrm{v})$ sucrose and kanamycin, and only NA and kanamycin. The sucrose sensitive colonies were selected from NA plus kanamycin plate and grown in $\mathrm{NB}$ medium overnight at $28^{\circ} \mathrm{C}$. The culture was then dilution-plated on NA containing $5 \%$ sucrose to select for resolution of the construct by a second cross-over event. The resulting deletion mutant of $x o p A F$ and double mutant of xopAF and avrGf1 was confirmed by PCR (data not shown). The complete $x o p A F$ and avrGf1 genes were complemented in the single and double mutants using pUFR053 and pUFR034 respectively. The resulting complement strains were Xcaw12879 $\triangle$ xopAF-53:xopAF, Xcaw12879 $A$ avrGf1-34: avrGf1 and Xcaw12879 $\Delta a v r G f \Delta x o p A F-34: a v r G f 1-53$ : $x o p A F$ were used in this study.

\section{Pathogenicity assay}

Pathogenicity assays were conducted in a quarantine greenhouse facility at Citrus Research and Education Center, Lake Alfred, FL. XccA306, Xcaw12879, and Xcaw $\Delta a v r G f 1$ strains were grown with shaking overnight at $28^{\circ} \mathrm{C}$ in $\mathrm{NB}$, centrifuged down and suspended in sterile tap water and the concentrations were adjusted to $10^{8} \mathrm{cfu} / \mathrm{ml}$. The bacterial solutions were infiltrated into fully expanded, immature leaves of Duncan grapefruit, Valencia sweet orange and Hamlin sweet orange, with needleless syringes [54]. The test was repeated three times with similar results. Disease symptoms were photographed 10 days post inoculation.

\section{Growth assay in planta}

XccA306, Xcaw12879, Xcaw $\Delta x o p A F, \mathrm{Xcaw} \Delta x o p A F-53$ : $x o p A F$, Xcaw $\Delta a v r G f 1$ and Xcaw $\Delta x o p A F \Delta a v r G f 1$ strains were grown with shaking overnight at $28^{\circ} \mathrm{C}$ in $\mathrm{NB}$, centrifuged down and suspended in sterile tap water 
and the concentrations we re adjusted to $10^{6} \mathrm{cfu} / \mathrm{ml}$. The bacterial solutions were infiltrated into fully expanded, immature leaves of Duncan grapefruit, Mexican lime and Valencia sweet orange with needleless syringes [54]. To evaluate the growth of various Xcc strains and mutants in these plants 2 inoculated leaves were collected from each plant at $0,2,4$, $7,10,14$ and 21 days. $1 \mathrm{~cm}^{2}$ leaf disks from inoculated leaves were cut with a cork borer and then ground in 1 $\mathrm{ml}$ sterile water. These were serially diluted and plated on NA plates. The bacterial colonies were counted after 3-day incubation at $28^{\circ} \mathrm{C}$. The test was repeated three times independently.

\section{Pectate lyase and proteinase assay}

XccA306 and Xcaw12879 were grown on nutrient agar at $28^{\circ} \mathrm{C}$, then suspended in sterile deionized water to the O.D. of 0.3 at $560 \mathrm{~nm}$. Hildebrand's medium A, B and C were used to test for pectolytic activity [69]. In short the medium contained bromothymol blue dye, calcium chloride, $2 \%$ sodium polypectate and $0.4 \%$ agar. The $\mathrm{pH}$ was adjusted to $4.5,7.0$ and 8.5 for the medium A, B and $\mathrm{C}$. One $\mu \mathrm{l}$ of the cultures were inoculated onto the plates and incubated at $28^{\circ} \mathrm{C}$ for 6 days before confirming pitting due to pectate lyase production. $10 \%$ skim milk agar was used to test the bacterial protease activity. The cultures were grown and suspended in sterile water as explained above. One $\mu \mathrm{l}$ of the cultures were inoculated onto the skim-milk plates and cultured at $28^{\circ} \mathrm{C}$ for 6 days to observe protease activity.

\section{Availability of supporting data}

The genome sequences of Xanthomonas citri subsp. citri strain $\mathrm{A}^{\mathrm{w}} 12879$ are available at GenBank under the accession numbers CP003778, CP003779 and CP003780. The RNA-Seq data from this study are available in the NCBI's Gene Expression Omnibus database under the accession number GSE41519.

\section{Additional files}

Additional file 1: Clustered regularly interspaced short palindromic repeats (CRISPRs) in X. citri subsp. citri str. $A^{\mathrm{w}} 12879$ genome predicted using CRISPRfinder.

Additional file 2: Dot-Plot comparison of unique cluster 4 from Xcaw12879 and genome of $X$. campestris pv. campestris strain 8004 done using MUMer. Red dots represent undisturbed segment conservation whereas blue dots indicate inversion.

Additional file 3: Prediction and comparison of the TAL effector codes encoded by $p$ thA genes of $X$. citri subsp. citri str. 306 , and $X$. citri subsp. citri str. Aw. Panel A: Prediction of TAL effector codes of PthAw1 and PthAw2. Panel B: The known TAL effector codes of PthA genes from XcCA. Panel C: Comparison of the TAL effector codes of PthAw2 and PthA4, homologs in Xcaw12879 and Xcc306 respectively.

Additional file 4: Summary of RNA-Seq data of Xcaw12879 and XccA306 in NB and XVM2.
Additional file 5: Correlation between biological replicates for RNASeq.

Additional file 6: Principal component analysis of DEG of $X$. citri subsp. citri str. 306 (A), and X. citri subsp. citri str. A 12879 (W) under NB and XVM2 conditions.

Additional file 7: Primers used in this study.

Additional file 8: RNA-seq validation by qRT-PCR. Comparison of gene expression by qRT-PCR and RNA-seq. The $\log _{2}$-fold change of each gene was derived from comparison of either WNB vs ANB or WXVM2 vs AXVM2. The 16S rRNA gene was used as an endogenous control in qRTPCR. Values of $\log _{2}$ fold change are means of three biological replicates. Error bars indicate standard deviation. Blue bars represent values from RNA-seq and yellow bars are values from qRT-PCR.

Additional file 9: Differentially expressed genes of $X$. citri subsp. citri str. 306 (A) in XVM2 medium as compared to NB.

Additional file 10: Differentially expressed genes of $X$. citri subsp. citri str. A $^{\mathrm{W}} 12879$ (W) in XVM2 medium as compared to NB.

Additional file 11: Differentially expressed genes between $X$. citri subsp. citri str. 306 (A) and X. citri subsp. citri str. A ${ }^{\mathrm{w}} 12879$ (W) in NB medium.

Additional file 12: Differentially expressed genes between $X$. citri subsp. citri str. 306 (A) and X. citri subsp. citri str. A ${ }^{\mathrm{W}} 12879$ (W) in XVM2 medium.

Additional file 13: Shared differentially expressed genes between X. citri subsp. citri str. 306 (A) and X. citri subsp. citri str. A 12879 (W) in both NB medium and XVM2.

Additional file 14: Differential expression of effector genes between $X$. citri subsp. citri str. 306 (A) and X. citri subsp. citri str. $A^{W} 12879$ (W) in both NB medium and XVM2 medium. FDR values are in parenthesis. The effector genes that pass cut-off value of 0.05 are marked in green.

\section{Competing interests}

The authors declare that they have no competing financial interests.

\section{Authors' contributions}

Conceived and designed the experiments: NW and NJ, Performed the experiments: NJ and MOA, Analyzed the data: NJ, NW, DK, FY, JBJ, FFW, JCS and JHG, Wrote the paper: NJ, NW, JBJ, FFW, JCS and JHG. All authors read and approved the final manuscript.

\section{Acknowledgements}

This work has been supported by Florida Citrus Research and Development Foundation and United States Department of Agriculture-Cooperative State Research Education and Extension Services Special Citrus Canker Grant Project 73402. Support was also provided, in part, by AFRI grant 2012-67013 -19384 from USDA NIFA(FW, JJ, NW, WF).

\section{Author details}

${ }^{1}$ Citrus Research and Education Center, Department of Microbiology and Cell Science, University of Florida, 700 Experiment Station Road, Lake Alfred, FL 33850, USA. ${ }^{2}$ Waksman Genomics Core Facility, Rutgers University Busch Campus, Piscataway, NJ 08854, USA. ${ }^{3}$ ICBR, University of Florida, Gainesville, FL 32611, USA. ${ }^{4}$ Department of Plant Pathology, University of Florida, Gainesville, FL 32611, USA. ${ }^{5}$ Department of Soil and Water Science, Citrus Research and Education Center, University of Florida, 700 Experiment Station Road, Lake Alfred, FL 33850, USA. ${ }^{6}$ Department of Plant Pathology, Kansas State University, 4024 Throckmorton Hall, Manhattan, KS 66506, USA.

${ }^{7}$ Departamento de Bioquímica, Instituto de Química, Universidade de São Paulo, São Paulo, SP 05508-000, Brazil. ${ }^{8}$ Virginia Bioinformatics Institute, Virginia Polytechnic Institute and State University, Blacksburg, VA 24060-0477, USA. 


\section{References}

1. Chan JW, Goodwin PH: The molecular genetics of virulence of Xanthomonas campestris. Biotechnol Adv 1999, 17:489-508.

2. Civerolo EL: Bacterial canker disease of citrus. J Rio Grande Val Hort SoC 1984, 37:127-145.

3. Stall RE, Civerolo EL: Research relating to the recent outbreak of citrus canker in Florida. Annu Rev Phytopathol 1991, 29:399-420.

4. Sun X, Stall RE, Jones JB, Cubero J, Gottwald TR, Graham JH, Dixon WH, Schubert TS, Chaloux PH, Stromberg VK, et al: Detection and characterization of a new strain of citrus canker bacteria from Key/ Mexican Lime and alemow in south Florida. Plant Dis 2004, 88:1179-1188.

5. Verniere C, Hartung JS, Pruvost OP, Civerolo EL, Alvarez AM, Maestri P. Luisetti J: Characterization of phenotypically distinct strains of Xanthomonas axonopodis pv. citri from Southwest Asia. Eur J Plant Pathol 1998, 104:477-487.

6. Schubert TS, Rizvi SA, Sun X, Gottwald TR, Graham JH, Dixon WN: Meeting the challenge of eradicating citrus canker in Florida - again. Plant Dis 2001, 85:17.

7. Rybak MA, Minsavage GV, Stall RE, Jones JB: Identification of Xanthomonas citri ssp. citri host specificity genes in a heterologous expression host. Mol Plant Pathol 2009, 10:249-262.

8. da Silva AC, Ferro JA, Reinach FC, Farah CS, Furlan LR, Quaggio RB, Monteiro-Vitorello CB, Van Sluys MA, Almeida NF, Alves LM, et al: Comparison of the genomes of two Xanthomonas pathogens with differing host specificities. Nature 2002, 417:459-463.

9. Jalan N, Aritua V, Kumar D, Yu F, Jones JB, Graham JH, Setubal JC, Wang N: Comparative genomic analysis of Xanthomonas axonopodis pv. citrumelo $\mathrm{F} 1$, which causes citrus bacterial spot disease and related strains provides insights into virulence and host specificity. J Bacteriol 2011, 193:6342-6357.

10. Moreira LM, Almeida NF, Potnis N, Digiampietri LA, Adi SS, Bortolossi JC, da Silva AC, da Silva AM, de Moraes FE, de Oliveira JC, et al: Novel insights into the genomic basis of citrus canker based on the genome sequences of two strains of Xanthomonas fuscans subsp. aurantifolii. BMC Genomics 2010, 11:238.

11. Jalan N, Kumar D, Yu F, Jones JB, Graham JH, Wang N: Complete genome sequence of Xanthomonas citri subsp. citri strain $A^{\mathrm{w}} 12879$, a restricted host-range citrus canker-causing bacterium. Genome Announce, 1:3. e00235-13. doi:10.1128/genomeA.00235-13.

12. Wengelnik K, Van Den Ackerveken G, Bonas U: HrpG a key hrp regulatory protein of Xanthomonas campestris pv. vesicatoria is homologous to two-component response regulators. Mol Plant Microbe Interact 1996, 9:704-712.

13. Midha S, Ranjan M, Sharma V, Pinnaka AK, Patil PB: Genome sequence of Xanthomonas citri pv. mangiferaeindicae strain LMG 941. J Bacterio/ 2012, 194:3031.

14. Sharma V, Midha S, Ranjan M, Pinnaka AK, Patil PB: Genome sequence of Xanthomonas axonopodis pv. punicae strain LMG 859. J Bacterio/ 2012, 194:2395.

15. Rodriguez-R LM, Grajales A, Arrieta-Ortiz ML, Salazar C, Restrepo S, Bernal A: Genomes-based phylogeny of the genus Xanthomonas. BMC Microbial 2012, 12:43

16. Siguier P, Perochon J, Lestrade L, Mahillon J, Chandler M: ISfinder: the reference centre for bacterial insertion sequences. Nucleic Acids Res 2005, 34:32-36.

17. Al-Saadi A, Reddy JD, Duan YP, Brunings AM, Yuan Q, Gabriel DW: All five host-range variants of Xanthomonas citri carry one pthA homolog with 17.5 repeats that determines pathogenicity on citrus, but none determine host-range variation. Mol Plant Microbe Interact 2007, 20:934-943.

18. Qian W, Jia Y, Ren SX, He YQ, Feng JX, Lu LF, Sun Q, Ying G, Tang DJ, Tang $H$, et al: Comparative and functional genomic analyses of the pathogenicity of phytopathogen Xanthomonas campestris pv. campestris. Genome Res 2005, 15:757-767.

19. Semenova E, Nagornykh M, Pyatnitskiy M, Artamonova II, Severinov K: Analysis of CRISPR system function in plant pathogen Xanthomonas oryzae. FEMS Microbiol Lett 2009, 296:110-116.

20. Büttner D, Bonas U: Regulation and secretion of Xanthomonas virulence factors. FEMS Microbiol Rev 2010, 34:107-133.

21. Escalon A, Javegny S, Vernière C, Noël LD, Vital K, Poussier S, Hajri A, Baureau T, Pruvost O, Arlat M, Gagnevin L: Variations in the type III effector repertoires, pathological phenotypes and host range of Xanthomonas citri pv. citri pathotypes. Mol Plant Pathol 2013, 14:483-496.

22. Kearney B, Staskawicz BJ: Widespread distribution and fitness contribution of Xanthomonas campestris avirulence gene avrBs2. Nature 1990, 346:385-386.

23. Alegria M, Souza D, Andrade M, Docena C, Khater L, Ramos C, da Silva A Farah $C$ : Identification of new protein-protein interactions involving the products of the chromosome and plasmid-encoded type IV secretion loci of the phytopathogen Xanthomonas axonopodis pv. citri. J Bacteriol 2005, 187:2315-2325.

24. Noël L, Thieme F, Nennstiel D, Bonas U: Two novel type III-secreted proteins of Xanthomonas campestris pv. vesicatoria are encoded within the hrp pathogenicity island. J Bacterio/ 2002, 184:1340-1348.

25. Thieme F, Szczesny R, Urban A, Kirchner O, Hause G, Bonas U: New type III effectors from Xanthomonas campestris pv. vesicatoria trigger plant reactions dependent on a conserved $\mathrm{N}$-myristoylation motif. Mol Plant Microbe Interact 2007, 20:1250-1261.

26. Nimchuk ZL, Fisher EJ, Desveaux D, Chang JH, Dangl JL: The HopX (AvrPphE) family of Pseudomonas syringae type III effectors require a catalytic triad and a novel $\mathrm{N}$-terminal domain for function. Mol Plant Microbe Interact 2007, 20:346-357.

27. Roden JA, Belt B, Ross JB, Tachibana T, Vargas J, Mudgett MB: A genetic screen to isolate type III effectors translocated into pepper cells during Xanthomonas infection. Proc Natl Acad Sci U S A 2004, 101:16624-16629.

28. Thieme F: Genombasierte Identifizierung neuer potentieller Virulenzfaktoren von Xanthomonas campestris pv. vesicatoria. Halle-Wittenberg: Mathematisch-Naturwissenschaftlich-Technische Fakultät der Martin-Luther Universität; 2008. PhD thesis.

29. Furutani A, Takaoka M, Sanada H, Noguchi Y, Oku T, Tsuno K, Ochiai H, Tsuge S: Identification of novel type III secretion effectors in Xanthomonas oryzae pv. oryzae. Mol Plant Microbe Interact 2009, 22:96-106

30. Jiang Y: The rice XA21-binding protein 25 is an ankyrin repeat-containing protein and required for XA21-mediated disease resistance. University of Florida: Department of Plant Pathology; 2007. PhD thesis.

31. Metz M, Dahlbeck D, Morales CQ, Al Sady B, Clark ET, Staskawicz BJ: The conserved Xanthomonas campestris pv. vesicatoria effector protein XopX is a virulence factor and suppresses host defense in Nicotiana benthamiana. Plant J 2005, 41:801-814.

32. Guidot A, Prior P, Schoenfeld J, Carrère S, Genin S, Boucher C: Genomic structure and phylogeny of the plant pathogen Ralstonia solanacearum inferred from gene distribution analysis. J Bacteriol 2007, 189:377-387.

33. Petnicki-Ocwieja T, Schneider DJ, Tam VC, Chancey ST, Shan L, Jamir Y Schechter LM, Janes MD, Buell CR, Tang X, Collmer A, Alfano JR: Genomewide identification of proteins secreted by the Hrp type III protein secretion system of Pseudomonas syringae pv. tomato DC3000. Proc Natl Acad Sci U S A 2002, 99:7652-7657.

34. Thieme F, Koebnik R, Bekel T, Berger C, Boch J, Büttner D, Caldana C, Gaigalat L, Goesmann A, Kay S, et al: Insights into genome plasticity and pathogenicity of the plant pathogenic bacterium Xanthomonas campestris pv. vesicatoria revealed by the complete genome sequence. J Bacteriol 2005, 187:7254-7266.

35. Mukaihara T, Tamura N, Iwabuchi M: Genome-wide identification of large repertoire of Ralstonia solanacearum type III effector proteins by a new functional screen. Mol Plant Microbe Interact 2010, 23:251-262.

36. Lorenz C, Kirchner O, Egler M, Stuttmann J, Bonas U, Buttner D: HpaA from Xanthomonas is a regulator of type III secretion. Mol Microbiol 2008, 69:344-360

37. Park DS, Hyun JW, Park YJ, Kim JS, Kang HW, Hahn JH, Go SJ: Sensitive and specific detection of Xanthomonas axonopodis pv. citri by PCR using pathovar specific primers based on hrpW gene sequences. Microbiol Res 2006, 161:145-149

38. Kim JG, Li X, Roden JA, Taylor KW, Aakre CD, Su B, Lalonde S, Kirik A, Chen $Y$, Baranage G, et al: Xanthomonas T3S effector XopN suppresses PAMPtriggered immunity and interacts with a tomato atypical receptor-like kinase and TFT1. Plant Cell 2009, 21:1305-1323.

39. White FF, Potnis N, Jones JB, Koebnik R: The type III effectors of Xanthomonas. Mol Plant Pathol 2009, 10:749-766.

40. Astua-Monge G, Minsavage GV, Stall RE, Davis MJ, Bonas U, Jones JB: Resistance of tomato and pepper to T3 strains of Xanthomonas 
campestris pv. vesicatoria is specified by a plant-inducible avirulence gene. Mol Plant Microbe Interact 2000, 13:911-921.

41. Noël L, Thieme F, Nennstiel D, Bonas U: cDNA-AFLP analysis unravels a genome-wide HrpG-regulon in the plant pathogen Xanthomonas campestris pv. vesicatoria. Mol Microbiol 2001, 41:1271-1281.

42. Swarup S, Yang Y, Kingsley MT, Gabriel DW: A Xanthomonas citri pathogenicity gene, $p$ thA, pleiotropically encodes gratuitous avirulence on nonhosts. Mol Plant Microbe Interact 1992, 5:204-213.

43. Boch J, Bonas U: Xanthomonas AvrBs3 type family-type III effectors: discovery and function. Phytopathology 2010, 48:419-436.

44. Boch J, Scholze H, Schornack S, Landgraf A, Hahn S, Kay S, Lahaye T, Nickstadt A, Bonas $U$ : Breaking the code of DNA binding specificity of TAL-type III effectors. Science 2009, 326:1509-1512.

45. Haas BJ, Chin M, Nusbaum C, Birren BW, Livny J: How deep is deep enough for RNA-Seq profiling of bacterial transcriptomes? BMC Genomics 2012, 13:734.

46. Patil PB, Bogdanove AJ, Sonti RV: The role of horizontal transfer in the evolution of a highly variable lipopolysaccharide biosynthesis locus in xanthomonads that infect rice, citrus and crucifers. BMC Evol Biol 2007, $7: 243$.

47. Kingsley MT, Gabriel DW, Marlow GC, Roberts P: The opsX Locus of Xanthomonas campestris affects host range and biosynthesis of lipopolysaccharide and extracellular polysaccharide. J Bacterio/ 1993 175:5839-5850.

48. Krylov VN: The role of horizontal gene transfer by bacteriophages in the origin of pathogenic bacteria. Russ J Genet 2003, 5:483-504.

49. Garavaglia BS, Thomas L, Zimaro T, Gottig N, Daurelio LD, Ndimba B, Orellano EG, Ottado J, Gehring C: A plant natriuretic peptide-like molecule of the pathogen Xanthomonas axonopodis pv. citri causes rapid changes in the proteome of its citrus host. BMC Plant Biol 2010, 10:51.

50. Gottig N, Garavaglia BS, Garofalo CG, Daurelio LD, Valentine A, Gehring C, Orellano EG, Ottado J: Xanthomonas axonopodis pv. citri uses a plant natriuretic peptide-like protein to modify host homeostasis. Proc Natl Acad Sci U S A 2008, 105:18631-18636.

51. Backert S, Meyer TF: Type IV secretion systems and their effectors in bacterial pathogenesis. Curr Opin Microbiol 2006, 9:207-217.

52. Astua-Monge G, Feritas-Astua J, Bacocina G, Roncoletta J, Carvalho SA, Machado MA: Expression profiling of virulence and pathogenecity related genes of Xanthomonas axonopodis pv. citri. J Bacteriol 2005, 187:1201-1205.

53. Schulte R, Bonas U: A Xanthomonas pathogenicity locus is induced by sucrose and sulfur-containing amino acids. Plant Cell 1992, 4:79-86.

54. Wengelnik K, Bonas U: HrpXv, an AraC-type regulator, activates expression of five of the six loci in the hrp cluster of Xanthomonas campestris pv. vesicatoria. Mol Plant Microbe Interact 1996, 12:3462-3489.

55. Guo Y, Figueiredo F, Jones J, Wang N: HrpG and HrpX play global roles in coordinating different virulence traits of Xanthomonas axonopodis pv. citri. Mol Plant Microbe Interact 2011, 24:649-661.

56. Lee SW, Jeong KS, Han SW, Lee SE, Phee BK, Hahn TR, Ronald P: The Xanthomonas oryzae pv. oryzae PhoPQ two component system is required for AvrXA21 activity, hrpG expression and virulence. J Bacteriol 2008, 190:2183-2197.

57. Yan Q, Wang W: High-throughput screening and analysis of genes of Xanthomonas citri subsp. citri involved in citrus canker symptom development. Mol Plant Microbe Interact 2012, 25:69-84.

58. Li J, Wang N: The wxacO gene of Xanthomonas citri ssp. citri encodes a protein with a role in lipopolysaccharide biosynthesis, biofilm formation, stress tolerance and virulence. Mol Plant Pathol 2011, 12:381-396.

59. Rigano L, Siciliano F, Enrique R, Sendín L, Filippone P, Torres P, Qüesta J, Dow J, Castagnaro A, Vojnov A, Marano M: Biofilm formation, epiphytic fitness, and canker development in Xanthomonas axonopodis pv. citri. Mol Plant Microbe Interact 2007, 20:1222-1230.

60. Larkin MA, Blackshields G, Brown NP, Chenna R, McGettigan PA, McWilliam $\mathrm{H}$, Valentin F, Wallace IM, Wilm A, Lopez R, et al: Clustal W and clustal X version 2.0. Bioinformatics 2007, 23:2947-2948.

61. Marchais A, Naville M, Bohn C, Bouloc P, Gautheret D: Single-pass classification of all noncoding sequences in a bacterial genome using phylogenetic profiles. Genome Res 2009, 19:1084-1092

62. Touchon M, Barbier P, Bernardet JF, Loux V, Vacherie B, Barbe V, Rocha EPC, Duchaud E: Complete genome sequence of the fish pathogen Flavobacterium branchiophilum. Appl Environ Microbiol 2011, 77:7656-7662.
63. Grissa I, Vergnaud G, Pourcel C: CRISPRFinder: a web tool to identify clustered regularly interspaced short palindromic repeats. Nucleic Acids Res 2007, 35:W52-W57. Web Server issue.

64. Kurtz SA, Phillippy A, Delcher AL, Smoot M, Shumway M, Antonescu C, Salzberg SL: Versatile and open software for comparing large genomes. Genome Biol 2004, 5(2):12.

65. Filiatrault MJ, Stodghill PV, Bronstein PA, Moll S, Lindeberg M, Grills G, Schweitzer P, Wang W, Schroth GP, Luo S, et al: Transcriptome analysis of Pseudomonas syringae identifies new genes, noncoding RNAs and antisense activity. J Bacterio/ 2010, 192:2359-2372.

66. Mortazavi A, Williams BA, McCue K, Schaeffer L, Wold B: Mapping and quantifying mammalian transcriptomes by RNA-Seq. Nat Meth 2008 5:621-628.

67. Benjamini $Y$, Hochberg $Y$ : Controlling the false discovery rate: a practical and powerful approach to multiple testing. J Royal Stat Soc 1995, 67:289-300

68. Livak KJ, Schmittgen TD: Analysis of relative gene expression data using real-time quantitative PCR and the $2_{T}^{-\Delta \Delta C}$ method. Methods 2001, 25:402-408

69. Hildebrand DC: Pectate and pectin gels for differentiation of Pseudomonas sp. and other bacterial plant pathogens. Phytopathology 1971, 61:7.

doi:10.1186/1471-2164-14-551

Cite this article as: Jalan et al:: Comparative genomic and transcriptome analyses of pathotypes of Xanthomonas citri subsp. citri provide insights into mechanisms of bacterial virulence and host range. BMC Genomics $201314: 551$

\section{Submit your next manuscript to BioMed Central and take full advantage of:}

- Convenient online submission

- Thorough peer review

- No space constraints or color figure charges

- Immediate publication on acceptance

- Inclusion in PubMed, CAS, Scopus and Google Scholar

- Research which is freely available for redistribution 